\title{
Wage Structure and Gender Earnings Differentials in China and India*
}

\author{
Jong - Wha $L E E^{a, *}$ \\ Dainn WIE
}

January 2017

\footnotetext{
$a_{\text {Korea University, Sungbuk-gu, Anam-ro 145, Seoul, 02841, Korea. (email: jongwha@korea.ac.kr) }}$

${ }^{b}$ National Graduate Institute for Policy Studies, 7-22-1 Roppongi, Minato-ku, Tokyo 106-8677, (email: wie-dainn@grips.ac.jp).

* Corresponding author. Tel: +82 23290 1600, Fax: +82 29234661
} 


\begin{abstract}
\end{abstract}
This study analyzes how changes in overall wage inequality and gender-specific factors affected the gender wage gap in Chinese and Indian urban labor markets in the 1990s and 2000s. We observe the significant expansion of skilled workers and the increase of overall wage inequality in both countries over the period. Analyses of micro data present that contrasting evolutionary patterns in gender wage gap emerged over the period, showing a widened wage gap in China but a dramatically reduced gap in India. In both countries, female workers' increased skill levels contributed to reducing the gender wage gap. However, increases in observed prices of education and experience worked unfavorably for high-skilled women, counterbalancing their improvement in labor market qualifications. Decomposition of changes in the gender wage gap shows that China's widened gap was attributable to gender-specific factors such as deteriorated observable and unobservable labor market qualifications and increased discrimination, especially against low- and middle-skilled female workers. For India, gender-specific factors and relatively high wage gains of low- and middle-skilled workers reduced the male-female wage gap. Our study suggests that consideration of overall wage structure, unobserved skills, and gender-specific factors such as unobserved labor market qualification and discrimination against women should be included in designing policies to promote gender equity and inclusiveness in labor markets.

JEL Code: J21, J24, J31

Key words: gender earning differential; wage inequality; skill premium; China; India 


\section{HIGHLIGHTS}

- We analyze the evolution of gender wage gap in Chinese and Indian urban labor markets using micro data.

- Gender wage gap widened in China but reduced dramatically in India in the 1990s and 2000s.

- Female workers' increased skills contributed to reducing the gender wage gap, but increases in observed prices of education and experience worked unfavorably for high-skilled women.

- China's widened gap was attributable to deteriorated observable and unobservable labor market qualifications and increased discrimination.

- In India, gender-specific factors and relatively high wage gains of low- and middle-skilled workers reduced the male-female wage gap. 


\section{ACKNOWLDGEMENTS}

The authors are grateful to Rohini Pande, Brajesh Panth, and seminar participants at the Yokohama National University, Hitotsubashi University, and the Osaka Workshop on Economics of Institutions and Organizations for helpful comments. We thank the Asian Development Bank for data support. We acknowledge support by a Korea University grant and research funds provided by Policy Research Center at National Graduate Institute for Policy Studies. 


\section{Introduction}

Labor markets in the People's Republic of China (China) and India experienced dramatic changes over the past two decades. In the 1990s and 2000s, the urban labor markets of both countries experienced significant increases in wage inequality and skill premium. Increased wage inequality is found to work against gender wage differentials in developed countries as female workers on average have lower level of skills than their male counterparts (Blau and Kahn 1997). Similarly, increasing wage inequality found in the two large developing countries can also aggravate the position of women in their labor markets. This paper makes contribution to existing literature by analyzing the effect of overall wage structure and unobserved characteristics on gender wage differentials in these countries using long-run microdata of two countries.

The comparison of China and India - two of the world's largest countries that have undergone significant economic and social transformations-contributes to understanding major developments in labor markets and gender gaps of developing countries over the past decades. The analyses based on cross-country comparison enable us to grasp the similarities and differences in labor market developments between China and India and draw useful implications for further improvement. The two countries had very different starting points in terms of gender gap in the labor market. In pre-reform China, almost all working age men and women were equally employed and also equally paid according 
to the administratively determined wage structure (Meng 2012). On the other hand, India had stagnant female labor force participation rate and significant male-female wage gap for more than two decades. This paper contributes to understanding how the benefits of economic development were distributed between men and women in the two developing countries.

A substantial body of literature has analyzed the evolution of gender wage gap and its sources in the United States and other advanced countries. Blau and Beller (1988) examined earnings differentials by gender from 1971 to 1981 and found increased female-male earnings ratio in the United States.

Blau and Kahn (1997), employing a technique developed by Juhn et al. (1991), found that females in U.S. had to counterbalance this unfavorable change in wage structure by improving their own human capital. They described this as "swimming upstream" and pointed out that the gender wage gap depends on overall wage structure as well as gender-specific factors. Blau and Kahn (2003) examined the change in gender wage gap in 22 countries during 1985-94 and found the inverse relationship between collective bargaining agreements and higher relative wage of women, suggesting the importance of wage-setting institution on gender wage gap. Datta et al. (2006) employed the same technique to U.S and Denmark and found that Denmark women experienced worsening wage gap due to increased returns to experience and deterioration of their relative position in residual. Also high-skilled women in Denmark experienced the greatest increase in the gender wage gap entirely due to their falling 
behind men in unobservable characteristics. This paper implements the same technique to disaggregate the gender wage gap into gender-specific factors and general wage structure factors and assess the relationship between overall wage inequality and gender wage differentials in China and India.

A number of papers have analyzed wage inequality and skill premium in labor markets in China and India. In China, returns to schooling were very low compared to other developing countries until the mid-1990s. Since the mid-1990s, however, wages in China have increased significantly for each additional year of schooling (Fang et al. 2012). Empirical studies based on micro data from the China Urban Household Survey and the Chinese Household Income Project Series (CHIPS) have found that rates of return to education in China were higher than those in most industrialized economies, and have increased over time (Ding et al. 2012; Li and Ding 2003; Zhang et al. 2005).

Rising education returns in China, beginning in the mid-1980s, have been partly attributed to the liberalization of labor markets and wage setting, particularly in urban areas (Zhang et al. 2005). Market-oriented reforms in China caused an upward shift in the demand for skilled workers and thereby increased the skill premium for educated workers (Meng 2012; Knight and Song 2003). Foreign-owned firms in China (Xu and Li, 2008) and trade liberalization (Han et al. 2012) are also found to be driving forces behind the rising skill demand in China.

In India, there has been a steady increase in the skill premium and wage inequality since the early 1980s (Kijima 2006), with rising demand for skilled male workers (Chamarbagwala 2006). Some 
studies point out that skill-biased technological changes in India have caused increasing returns to skills (Berman et al. 2005; Kijima 2006). According to Mehta and Hasan (2012), the increase in wage inequality between 1993 and 2004 was largely attributable to changes in industry wages and skill premiums.

Using the 2005 India Human Development Survey, a nationally representative survey, Agrawal (2012) showed that private returns increased with the level of education in India due to an increasing demand for skilled workers and a limited supply of employable graduates. In India, graduates from quality colleges and universities can be hired by global firms and foreign enterprises, as well as call centers that provide significantly higher salaries than small-sized, domestic firms. On the other hand, Shastry (2012) suggested that globalization measured as costs of learning English across Indian districts increases education of workers and thereby mitigates the increase in wage inequality.

There are a growing number of empirical studies on the gender earnings differential in each country, but they do not reach clear consensus. According to Gustafsson and Li (2000), the gender wage gap in urban China was relatively small, but increased between 1988 and 1995 as a result of the deterioration of wages paid to female workers with limited experience and skill. A more recent study by Zhang et al. (2008) found that the same trend continued across the earnings distribution, at least until 2001, but the gap widened greatly at the upper end of the distribution during the years 2001-2004. They argued that the widening of the urban gender wage gap over this period reflected rapid increases in 
returns to both observed and unobserved skills in China, which worked more favorably for men's higher skill levels. Fang et al. (2012) also found a striking gender disparity in returns to education, with the returns for each additional year of schooling for males being higher than for females from 1997-2006.

Gender differences in wage are quite pervasive in India. Women wage workers work fewer days per year, and are paid considerably less than men across educational levels (except those who have completed a secondary level education in urban areas), in both rural and urban areas (Desai et al. 2010). Bhalla and Kaur (2011) suggest that gender wage differences in India are partly due to gender differences in education and work experience. On average, compared to males, female workers are less educated and less experienced, which is partly due to childbearing. Chamarbagwala (2006) argued that during the 1980s and 1990s, despite a considerable widening of the skill-wage gap, the gender wage differential narrowed significantly among high school and college graduates, suggesting increased demand for skilled workers and especially for skilled women contributed significantly to the decline in gender disparity. Menon and Rodgers (2008) analyzed household data from India over the years 19832004 and suggested that India's trade liberalization increased women's relative wages and employment as increased competition, caused by trade, diminished discrimination against female workers.

Using micro data, this paper focuses on analyzing changes in wage inequality and gender earnings differentials in China and India during the 1990s and 2000s. We find significant increases in wage inequality and skill premium in urban areas of China as well as India. We also observe significant 
gender earning differentials in both countries throughout the period. Interestingly, the gender wage gap evolved very differently in each country, as it increased in China while improving in India. ${ }^{1}$ Although there is ample literature on the labor markets and wage structures in these economies, as far as we are aware no paper has explicitly focused on comparing these two countries, especially on the striking differences in the evolution of their respective gender wage gaps. ${ }^{2}$ An important issue is to analyze the role of wage structure and skill premium in influencing the gender wage gap. Since an increasing skill premium tends to widen the gender wage differential if females, on average, have lower skill levels and less experience, the trend in decreasing gender wage differentials in India is more surprising and needs a more thorough analysis.

Women's education and experience levels have steadily increased over the last two decades, contributing to a declining gender wage gap in both the Chinese and Indian economies. However, increasing skill premium can negatively affect women since they are relatively less skilled and experienced. If the price of observed and unobserved skills increases, it not only affects overall wage inequality, but also widens the gender wage differential by punishing relatively unskilled female workers. Also, changes in unobserved qualification or discrimination can play a major role in gender wage gap over time.

The remainder of this paper is organized with Section II describing our micro data sources and presenting an overview of recent trends in wage structure and gender wage differentials in China and 
India. In Section III, we examine whether change in supply and demand of labor inputs in different categories can explain change in the gender gap over two decades by utilizing the methodology of Katz and Murphy (1992). Section IV adopts the methodology of Juhn et al. (1991) and Blau and Kahn (1997)

to decompose changes in the overall gender wage gap and explore the differences in the Chinese and Indian labor markets. Section $\mathrm{V}$ uses the same methodology to further examine changes in the gender wage gap by skill level and concluding remarks follow in Section VI.

\section{Data Overview and Recent Trends in Wage Structure and Gender Wage Differentials}

\section{A. Trends in Wage Inequality and Skill Premium}

\section{Data Descriptions}

An examination of the evolution of the wage structure and its relationship with skill level requires good quality micro data with detailed information on workers' wage and skill levels. Availability of longitudinal data that is consistent over time is crucial in order to determine whether the changes in wage structure are a secular trend and not caused by temporary shocks in the economy.

For India, we use the National Sample Survey's (NSS) Employment and Unemployment data, 
which is considered to be reliable and consistent over time. To examine long-run wage trends by worker skill level, the dataset covers five waves of the survey (1987-1988, 1993-1994, 1999-2000, 2005-2006, and 2009-2010). Each wave has more than 100,000 observations and contains both employed workers in the formal sector and self-employed or unpaid workers in the informal sector.

For China, four rounds $(1988,1995,2002$, and 2009) of the CHIPS datasets are analyzed, focusing on urban areas. These datasets contain labor force information over a large, nationally representative sample of around 60,000 to 80,000 individuals, covering more than 16 provinces in the major regions of China. Each wave of CHIPS data has a different sample of provinces. To maximize consistency of data over time, we only use a set of provinces that are included in all four waves of the data set. $^{3}$

Throughout our analyses, we focus on the urban areas of the two countries in order to achieve a direct comparison. ${ }^{4}$ We exclude the rural area of China, as more than 90 percent of observations do not report their wage information. We restrict the sample to full-time workers aged 18-60 years. In the CHIPS dataset, we identify full-time workers as people who have worked for more than 170 hours per month in their primary job. ${ }^{5}$ In India, we apply a more restrictive criterion as the NSS data set has more information about workers, and define a full-time worker as a person who works more than five days per week without holding a second job. We exclude workers who are self-employed or engaged in unpaid family business and also exclude individuals with reported wages of zero despite their full-time paid 
working status. We use real weekly earnings from the primary job for NSS data and monthly earnings from the primary job for CHIPS data to avoid measurement errors from computing hourly wage. ${ }^{6}$

One caveat of using standard labor force data is that we cannot identify exact years of experience for female workers. Women tend to have career interruptions in their lifetimes, making it difficult to measure years of experience accurately. However, our results are robust by using different measures of experience ${ }^{7}$, indicating that measuring experience would not affect analyses in any specific direction.

\section{Trends in Skill Premium and Wage Inequality}

Using our micro data, indicators for wage inequality, skill premium, and gender wage differentials are constructed. As change in returns to skill is a key factor in understanding the structure of wage and its effect on gender inequality, the evolution of wage inequality is investigated by skill group, with the source of change in the skill premium being identified.

\section{$<$ Figure 1, A\& B Here>}

The period of rapid development in China and India is characterized by increasing wage inequality. As shown in Figure 1.A, average real wages in urban China increased at an accelerated pace over 1988-2009, especially 2002-2009. Economic growth was of greatest benefit to the skilled group, proxied here by the 90th percentile. Among the median group (50th percentile) real wages rose, albeit 
less rapidly than that of the skilled group. The unskilled group (10th percentile) gained the least benefit from economic growth over the same period.

Average real wages and wage inequality in urban India also rose over the period 1988-2010.

Figure 1.B shows average real wages in urban India continued to rise over 1988-2010, although they grew at slower rates than in urban China. Unlike in China, the median group (the 50th percentile) gained the least benefit from economic growth. Meanwhile the gap in real wages among the skilled and unskilled groups (proxied here by the 90th and the 10th percentiles) increased significantly.

In urban China, we assess recent changes in the skill premium by classifying workers into four categories. Figure 2.A shows that most skill premiums increased except the premium for workers who graduated senior high school relative to workers whose educational attainment is lower than primary school. It is important to note that the premium for college graduates increased sharply during the period 1995-2002. These trends imply that an increase in the skill premium can be a significant source of rising wage inequality in China. In urban India, skill premiums for secondary and college graduates were kept quite high throughout the period, compared to those in China (Figures 2.A and 2.B), which may reflect the conditions in the supply of and demand for skilled labor. The premium for workers having a college degree over those with lower education increased significantly.

$<$ Figure 2, A\& B Here>

Many factors other than changes in the skill premium can also contribute to increasing wage 
inequality, so we examine whether the inequality level in unobserved characteristics also changes over time. Log real wage is regressed on experience and its square and on education (i.e., years of schooling). The residual from this regression captures the dispersion in wages within each demographic group. The difference in the log wages of those at the 90th and 10th percentiles in the wage distribution is then calculated.

$<$ Figure 3, A\& B Here>

Figure 3.A shows that residual wage differentials increased for both male and female workers in urban China from 1988 to 2009 . Not only has overall wage inequality expanded but within-group wage inequality also increased at the same time, except for females, during the period from 2002 to 2009. The rise of within-group wage inequality implies that low-skilled workers within each category benefited less than the high-skilled ones.

Figure 3.B shows steady increases in residual wage differentials for both male and female workers in urban India. The within-group wage inequality for males increased more rapidly than that for females over the period. While the gap had reduced over time, the wage differentials for males remained below that for female workers in 2009.

\section{B. Trends in Gender Wage Differentials}




\section{Trends in Gender Wage Differentials}

Table 1 shows trends in male and female wages for the past two decades in urban labor markets

of China and India. In China, women's relative wages deteriorated during its fast economic development, with the average wage for females decreasing from about 85 percent in 1988 to about 72 percent of the average male wage in 2009. The male-female differential of the log average real wage almost doubled from 0.163 in 1988 to 0.298 in 2009 . We also calculate the relative position of females in the male wage distribution. The mean female percentile in the male wage distribution deteriorated from 42.2 in 1988 to 38.1 in 2009.

<Table 1 Here>

On the contrary, in India, the average real wage for females increased from 68 percent in 1988 to about 82 percent of the average male wage in 2010. The differential of the log real wage dropped from 0.590 in 1988 to 0.382 in 2010 . The mean female percentile in the male wage distribution was only 32.8 in 1988 but rose to 39.5 in 2010. All these indicators show that the gender wage differential decreased sharply over the two decades in India. While the magnitude of the gender wage gap remains large both in China and India, recent movement of the gap in each country shows a sharp contrast.

$<$ Figure 4, A\& B Here>

We also examine whether the change in the gender wage gap is universal across wage distribution. Figure 4.A shows that in urban China, the gender gap in log monthly earnings increased in 
all selected percentiles of wage distribution. The magnitude of increase was large, particularly among the top percentile (high-skilled) groups. In contrast, the gender gap in the log weekly earnings declined in all selected percentiles of wage distribution in India. The magnitude of decline was particularly large in the middle percentiles and small at the top percentile.

\section{Labor Force Composition and Gender Wage Gap}

Change in the labor force composition of female workers can influence the estimated gender wage gap. If more educated women are likely to stay in the labor force over time, the magnitude of the gender gap would be underestimated. On the other hand, if labor force participation of women starts from the most educated women and then expands to less educated women, widening of the gender wage gap would be overestimated due to the change in the labor force composition.

\section{$<$ Figure 5, A\& B Here>}

Figure 5.A shows that the female labor participation rate sharply declined in urban China over two decades; this change in labor force composition may affect the gender wage gap. In India, the overall labor force participation rate of female workers hovered at around 20 percent over the period

(Figure 5.B). India's female labor force participation rate ranks among the lowest in the world. ${ }^{8}$ While the labor participation rate remained relatively stable over time, composition of the female labor force changed significantly over two decades; the share of skilled women increased while that of the least 
skilled women declined at the same time.

To acquire a selection-corrected gender wage gap, we adopt techniques such as Heckman's (1979) two-step estimation and selectivity corrected estimation according to probability of being in the labor force. Our results show that changes in labor force composition of women did not significantly affect the secular trends of the gender wage gap.

First, we apply Heckman's two-step estimation. Our sample consists of full-time workers between ages 18 and 60. We classify all persons as either working full-time or not. Using all prime-age women in our labor force surveys, we estimate the following first step equation:

$$
P_{t}(z)=\operatorname{Prob}(L=1 \mid z, g=1)=\Phi\left(Z \delta_{t}\right)
$$

where $P_{t}(z)$ indicates the probability of being in the labor force and $\mathrm{g}$ is a dummy variable indicating women. $\mathrm{Z}$ includes years of education, years of experience, and our instrumental variables. The set of instrumental variables includes number of children aged 0-6, number of minor children, and marital status. We assume that $P_{t}(z)$ is 1 for men.

In the second stage, we include the inverse Mills ratio in the regression to control for selection into the labor force:

$$
w_{i t}=X_{i t} \beta_{t}+g_{i} r_{t}+g_{i} \theta_{t} \lambda\left(Z_{i t} \delta_{t}\right)+u_{i t}
$$

where $w_{i t}$ denotes log wage and $\lambda\left(Z_{i t} \delta_{t}\right)$ the inverse Mills ratio. In this equation, $g_{i} r_{t}$ captures the selection-corrected gender wage gap. 
<Table 2 Here>

Table 2 demonstrates estimates of the gender wage gap based on ordinary least squares (OLS) and two-step estimation techniques. It shows that OLS and two-step estimates are not so different in urban China, indicating that selection is not a major driving force of the gender wage gap. In urban India, the results show that there is a sizable negative effect to selection into the labor market. The selection-corrected gender wage gap is much smaller than that of OLS; however, it still shows declining trends over two decades.

We adopt alternative specifications to correct for the selection of working women and further examine the robustness of the estimated change of the gender wage gap. As discussed earlier, change in the selection into the workforce can bias our estimated gender wage gap. First, we estimate probability to work for women by year and area. In China, the labor force composition sharply increased; therefore, we eliminate a set of women who are the least likely to work so that we can have a common set of women in our sample across years. In India, labor force participation did not change much over the two decades. However, there was compositional change; less-skilled women dropped out of the workforce while higher-skilled women entered the labor market. Therefore, we again exclude women with the lowest probability to remain in the labor force.

Second, we take into account the potential effect of women's marital status on their labor force participation decision. If more women delay marriage to receive different treatment in the labor market, 
change in the composition of the women's labor force by marital status may drive the gender wage gap regardless of other factors. Therefore, we exclude non-married women as well as women with low probability to remain in the market.

<Table 3 Here>

Table 3 shows that even after excluding women with a low probability to work in the labor force, the gender wage gap increased in urban China while it declined in India. Not only the direction of change in the gender gap, but also the magnitude of the estimated gender wage gap is quite similar with what was estimated using the simple OLS technique. In India, the magnitude of decrease in the gender wage gap is smaller when we include only married women in our sample, implying that much of the gender wage gap decrease was driven among young, unmarried women in the labor force.

In sum, the experiments in this section show that there is an increasing gender wage gap in China and a decreasing gender wage gap in India, even after labor force selection is controlled.

\section{Supply-Demand Analyses of Two Labor Markets}

\section{A. Data Construction and Empirical Strategy}

In this section, we examine whether change in relative supply and demand of labor inputs can explain change in the skill premium and gender wage differential in China and India. We utilize the 
methodology of Katz and Murphy (1992) to analyze the changes in relative wages and relative supplies

of the two countries. Katz and Murphy (1992) use a simple supply-demand framework to explain changes in the wage structure of the United States in the 1980s.

We construct two samples: a wage sample and a count sample. The wage sample includes full-time workers who are reported to work more than 170 hours per month at their main job in China or five days per week in India. The count sample is constructed to calculate the measure of relative labor supply in urban areas of China and India. The count sample uses all workers whose wages and education levels could be identified.

To examine the movement of relative supply and relative wage of various demographic groups, both count sample and wage sample are divided into 32 categories by workers' gender, education level, and experience level. The fixed weight of the average employment share for 32 cells among all workers during the entire sample period is used to construct aggregate measures in the wage sample, while the count sample uses the fixed weight of the average relative wage for 32 cells.

\section{B. Results from China}

Table 4 shows changes in relative wages across different demographic groups from 1988 to 2009 and two sub-periods, 1988-2002, and 2002-2009. Overall, relative wages showed a sharp increase during the period, reflecting fast economic growth. Both male and female workers acquired higher 
wages; however, male workers gained more than female workers.

<Table 4 Here>

Over the two decades analyzed, more educated workers gained the most among both females and males. The period 2002-2009 was an exception, where female workers with high school degrees gained the least while female workers with elementary school educations gained the most. Less experienced workers also gained the most, which reflects that many of these young workers had higher educational achievement.

\section{<Table 5 Here>}

Can change in the relative supply of workers in different education categories explain changes in skill premium trends by gender? Tables 4 and 5 show that relative supply alone cannot fully explain change in relative wage. The relative supply of workers with college degrees increased the most throughout the sample period; however, their relative wages increased the most at the same time. It indicates that there was a demand shift toward more educated workers, both female and male. The relative supply of less experienced workers decreased from 1988 to 2002, which partly explains an increase in premium for younger workers at the same time. However, the supply of less experienced workers as well as their wages increased sharply from 2002 to 2009, implying there was also growing demand for younger workers.

What about gender differences in wage gain? Female workers' wage gains were generally 
smaller than that of male workers across all education levels over the two decades except for elementary and junior secondary education in the 2002-2009 period (Table 4). On the other hand, relative supply of workers with college degrees increased more sharply among female workers than male workers, which may explain why relative wage gains of female workers with college degrees is smaller than that of male workers with college degrees. However, for other groups of workers, relative supply changes cannot explain the movement of relative wages. For example, despite the fact that relative supply of low-educated workers decreased by a greater magnitude among female workers than male workers, relative wage gains were even smaller for females than that of their male counterparts in 1988-2002. This may indicate a demand shift from less educated workers toward more educated workers was more prominent for female workers than males.

The movements in relative wage and relative supply show that there were demand shifts toward more skilled, younger workers. However, the differentials in the magnitude of change by gender cannot be explained simply by gender differential in relative supply and demand shifts. Some other factors can also affect male and female workers in different ways.

\section{Results from India}

Table 6 shows changes in real wages of Indian workers across different demographic groups for periods 1988-2000, 200-2005, and 2002-2009. There was an increasing trend in real wages over two 
decades, but the magnitude of increase is much smaller than that in China. However, in India, the increase in real wages was greater among female workers than male workers, especially from 2005 to 2010.

\section{<Table 6 Here>}

Similar to China, workers with university degrees or above gained the most among females and males over the overall period. The next group to benefit the most was the least educated group, including workers without literacy. Less experienced and younger workers gained the most, possibly due to their higher education levels.

Table 7 shows that there was a sharp decrease in the number of least educated workers implying that decline of relative supply can explain an increase in their wages. However, as relative supply of college-educated workers increased sharply over two decades, an increase in their education premium suggests demand shifted more favorably to this group. Hence, the overall pattern of relative wage changes seems to support relative supply changes and demand shifts toward more educated workers.

\section{<Table 7 Here>}

However, gender differences in wage gain suggest that factors aside from simple demand and supply changes were working in the Indian labor market. While relative supply of college-educated workers increased more rapidly among female workers than male workers, their relative wages increased by almost the same magnitude. Among the workers with primary educations or lower, the 
decrease in relative supply of male workers was much greater than that of female workers. However, female workers experienced greater increases in their relative wages.

The evolution of relative wage and relative supply show that there were demand shifts toward more educated workers in urban India. In addition, the least skilled group experienced a sizable increase in their wages with a sharp decline in their relative supply. However, some gender-specific factors other than relative supply and demand changes can influence gender wage differentials.

\section{Decomposition of the Gender Wage Gap}

\section{A. Model Specification and Implementation}

In order to analyze change in the gender wage gap in the United States, Blau and Kahn (1997) adopt the technique developed by Juhn et al. (1991) in their analysis of the trends in the U.S. blackwhite wage differential. Their technique allows us to decompose the residual wage differential into changes in unmeasured skills (calculated as percentile position in residual distribution) and prices of those unmeasured skills (dispersion of residual). As Figure 3 shows, China and India experienced different evolutions of residual inequality during the sample period. Using June et al. (1991) and Blau and Kahn (1997)'s technique, we can decompose changes in gender wage gap into price and quantity effects of both observed and unobserved parts. 
Assume the following male wage equation:

$$
Y_{i t}=X_{i t} B_{t}+\sigma_{t} \theta_{i t}
$$

where $i$ indicates each male worker and $t$ denotes year. $Y_{i t}$ denotes the log of wages while $X_{i t}$ indicates observable variables and $B_{t}$ indicates a vector of coefficients. $\sigma_{t}$ indicates the level of male residual wage inequality while $\theta_{i t}$ is standardized residual. The male-female log wage gap for year $t$ is defined as:

$$
D_{t} \equiv Y_{m t}-Y_{f t}=\Delta X_{t} B_{t}+\sigma_{t} \Delta \theta_{t}
$$

,where subscripts $\mathrm{m}$ and $\mathrm{f}$ denote male and female averages respectively and prefix $\Delta$ denotes average male-female differences for the variables immediately following. Equation (4) shows the gender wage differential can be decomposed into two parts: difference in observed labor market qualifications $\left(X_{t}\right)$ weighted by their market prices $\left(B_{t}\right)$ and difference in the relative position in residual $\left(\theta_{t}\right)$ inflated by overall wage dispersion $\left(\sigma_{t}\right)$.

The change in the gender wage gap between two time points-year 0 and year $1-$ can then be decomposed as follows:

$$
D_{1}-D_{0}=\left(\Delta X_{1}-\Delta X_{0}\right) B_{1}+\Delta X_{0}\left(B_{1}-B_{0}\right)+\left(\Delta \theta_{1}-\Delta \theta_{0}\right) \sigma_{1}+\Delta \theta_{0}\left(\sigma_{1}-\sigma_{0}\right)
$$

Now we have four components explaining the change in the gender wage differential. The first term represents a portion contributed by change in observed measures; specifically, it reflects the contribution of changing male-female differences in observed labor market qualifications such as 
education and job experience. The second term reflects the effect of changing prices of observed labor market qualifications for males.

The third term is defined as gap effect and measures the effect of changing differences in the relative wage position of male and female after controlling for observed qualifications. If male wage inequality does not change, this term only shows the change in the percentile rankings of female wage residuals. For example, discrimination against women or lack of unobserved skills in female workers relative to males would change female workers' position unfavorably in the residual distribution. This change in position would be captured by the gap effect. Finally, the fourth term measures change in the prices of unobserved characteristics. When this term gets larger, being in relatively low position in the residual distribution receives more punishment than before, thereby widening the gender gap if on average female workers' position is relatively low in residual distribution.

The first and third terms measure the portion of the gender wage gap due to gender-specific factors such as labor market qualification or relative position in the residual distribution, while the second and fourth terms measure the portion due to change in overall wage structure.

We employ the human capital model and full model to estimate wage equality. Human capital model specification employs the education and experience variables of each worker. Full model specification adds one-digit industry and occupation codes, and regions. ${ }^{9}$ Thus, the full model investigates whether specific occupations, industries, and regions are driving the changes in the 
decomposition results. For instance, there can be entry barriers for women in certain industries or occupations.

To acquire the change in the observed qualifications, we estimate wage regression using male samples in year 1 . Then, using estimated coefficients, we calculate estimated wages of female workers in year 1 . We also calculate imputed wages of female workers and male workers in year 0 . The first term is then calculated as the gender difference in average predicted wage of year 1 minus gender difference in average imputed wage of year 0 .

The second term measures the effect of change in price on observed characteristics. We estimate wage regression using male workers in year 0 and the calculated predicted wage of males and females in year 0 . Then, we calculate the second term as the difference in gender gap in the average of imputed wage of year 0 and the average of predicted wage of year 0.

To acquire the gap effect and change in unobserved characteristics, we run wage regression of male workers in year 0 and acquired female workers' position in male workers' residual distribution. Using the position of those female workers, we calculate the imputed residual of female workers in year 1. The gap effect is calculated as the difference between the average of the actual residual of female workers in year 1 and their imputed residual of year 1. This term captures change in relative position of female workers in residual distribution.

Finally, we calculate the fourth term as the difference between the imputed residual of female 
workers in year 1 and average residual of female workers in year 0 . The term captures change in dispersion of unobserved characteristics where the female workers' relative position is unchanged.

\section{B. Estimation Results of the Human Capital Model}

Table 8 summarizes the decomposition results of the gender wage gap in urban China and urban India using the human capital model.

In Column 1, the mean value of female residual from male wage regression, which contains unobserved parts of the wage gap, more than doubled from 1988 to 2009 in urban China. The residual term represents unobserved characteristics and discrimination that cannot be explained by controlled explanatory variables. The mean female residual percentile decreased from 45.5 in 1988 to 38.5 in 2009 in the human capital model. Estimation results consistently show that an unexplained gender gap widened in China over the period.

<Table 8 Here>

Table 8, Column 1, Panel B shows how unexplained and explained characteristics contributed to the increasing gender wage gap in urban China over two decades. Presented as a log monthly wage, the gender wage gap increased by $0.135 \log$ points over the period. ${ }^{10}$ Increased educational attainment of female workers contributed to reducing the gender wage gap, but its effect was dominated by the opposite price effect of education. The observed price effect is positive, indicating that the prices of 
education and experience changed to the direction of expanding the male-female wage differential.

Unexplained characteristics drove most of the change in the Chinese gender wage gap. The gap effect is significant, amounting to 0.239 . Thus, women's position in residual distribution was aggravated significantly over the period, which is attributable to either deterioration in unobservable qualifications of female workers or an increase in discrimination against female workers.

The fourth term captures wage inequality based on the change in the dispersion of unobserved characteristics, interacting with female workers' relatively unfavorable position in the distribution in the initial year. The estimate of the fourth term is positive, representing that the penalty for being in a relatively unfavorable position decreased over time.

The estimated positive third term implies that female workers received more discrimination and found themselves in a more unfavorable position in the residual distribution over time. At the same time, however, according to the estimated fourth term, the wage gap between each position became smaller than before, thereby eventually contributing to a narrow wage gap between female and male workers Column 2 of Table 8 summarizes the decomposition of the 1988-2010 gender wage gap using the human capital model in urban India. It shows that the mean value of female residual from the male wage equation slightly declined over time. The mean of female residual percentile also rose from 30.2 in 1988 to 35.8 in 2010 over time. Hence, in contrast to China, an unexplained gender gap declined in India over the same period. 
Panel B of Table 8 shows that the gender wage gap reduced by 0.208 log points in India, with further decomposition results showing the factors responsible for this sharp decrease. Increased human capital of female workers contributed significantly to the decline of the gender wage gap over time, amounting to about 30 percent of the total gender gap reduction in urban India.

The estimated observed price effect is negative, indicating that the prices of skill and experience changed to the direction of reducing the male-female wage differential. As earlier figures indicate, the premium for high-skilled workers increased. However, the low-skilled group gained more than the medium-skilled. Since female workers are more likely than males to be in the least skilled group, the wage gain of the low-skilled group contributed to the reduction of the gender wage differential.

The estimated gap effect is large and negative, indicating that women's position in residual distribution improved over the period. It could reflect improvement in unobservable qualifications of female workers or a decrease in discrimination against female workers, especially those who participated in urban labor markets. The estimated negative fourth term also indicates that as the penalty for being in a relatively unfavorable position becomes smaller, the gender wage gap narrows.

On the whole, our decomposition results show that the difference in the movements of the gender wage gaps in China and India comes from the difference in evolution of wage structures and relative positions of female workers in the residual distributions of both countries. In both China and India, female workers are catching up to their male counterparts by obtaining more education and work 
experience.

However, in urban China, the relative position of female workers deteriorated, implying that they need further training in unobserved skills or need more bargaining power to prevent discrimination in the labor market. In India, on the other hand, wage inequality in the lower half of the distribution decreased and thereby contributed to narrowing the gender wage gap. Catching up of human capital, fast improvement of wages for low-skilled workers, and declining discrimination were important determinants in the declining gender wage gap.

\section{Estimation Results of the Full Model}

Table 9 presents the estimation results of the full model. In urban China, there was a sizable gap

effect when we estimated the human capital model. The estimation of the full model, which considers industry and province fixed effects, demonstrates that the magnitude of the gap effect reduces to about a half of that under the human capital model, but remains positive and sizable. It implies that unobserved skills of female workers within narrowly defined demographic groups deteriorated over the period. For example, among college graduates, female workers may have obtained lower-quality education and skills training that are not well matched with their jobs. Alternatively, female workers had lower bargaining power in the labor markets compared to their male counterparts over time. More detailed 
micro data of the Chinese labor market would help analyze these conjectures in the future.

<Table 9 Here>

In urban India, the estimation results of the full model confirm the main results of the human capital

model. The gender-specific factors such as women's improvement in skill, experience, and affiliated industry explain most of the reduction in the gender gap over the period. Further, observed price effect

was favorable to female workers. Its contribution to the reduction of overall wage inequality becomes much larger in the full model because wage differentials by occupation, industry, and state fixed-effects constituted a great part of observed price effect.

The size of the gap effect in India was significantly smaller compared to the estimate in the human capital model. It suggests that relative improvement in women's position in residual distribution was mainly caused by the inflow of female workers into better-treated industries, occupations, or regions. On the other hand, the effect of unobserved prices does not show much difference from those estimates in the human capital model.

\section{Gender Wage Differential and Skill Level}

\section{A. Motivation}

In analyzing gender wage gap trends by skill group, most of the increase in wage inequality 
came from demand for more skilled workers in both countries. As both labor markets have common trends for skilled workers, examination of the gender wage gap by skill level can give us insights into common factors behind both markets.

In addition, the labor market for skilled workers has its own importance worthy of analysis. If the overall wage structure effect becomes unfavorable for high-skilled women, it implies the gap between women and men widens as women improve their human capital and move up in the wage distribution. As more women acquire higher education, it may be more difficult for them to become equal to their male partners.

We estimate wage equations using the full model for a sample of pooled male workers in 1988 and 2010 (2009 for China). Under the assumption that predicted wage from these estimations reflects labor market skill, we then divide men and women by gender into three skill categories in each year based on the percentile of predicted wages: $0-30,30-70$, and 30-100. Therefore, the concept of skill is relative and determined within year and by gender.

\section{B. Estimation Results}

Table 10 demonstrates decomposition of the gender wage differential by workers' skill level in urban China. Panel A shows that real wages of both male and female workers increased significantly for all skill levels. Over the two decades, rapid wage increase occurred with expansion of the gender wage 
gap. Mean female residual from male wage regression also decreased in all skill levels, implying that unobserved qualifications or wage structure contributed to increasing the gender wage gap.

$<$ Table 10 Here>

Panel B of Table 10 describes differences of each factor affecting gender wage differentials across skill groups. There are some notable differences across skill groups. Increase in wage inequality worked especially against high-skilled women even though they tried hard to catch up to their male counterparts in terms of observed qualifications. For medium- and low-skilled groups, their improvement in observed skills was much smaller than that for the high-skilled group. For all skill groups, gaps in unobserved skills or discrimination were driving forces behind the increased gender gap.

Table 11 shows decomposition of the gender wage differential in urban India. Panel A shows that improvement in wage trends is different across the skill groups. Log real wage of male workers increased for low-skilled and high-skilled workers, while there was almost no change for medium-skilled workers. At the same time, women's wages improved sharply for all skill levels, reducing the gap with male workers. Women's relative position of residual in male distribution also improved over time.

<Table 11 Here>

Panel B of Table 11 describes contributions of each factor to the gender wage differential across skill groups. In all skill levels, improvement of observed skills contributed to a decrease in the gender 
wage gap. For low- and medium-skilled groups, both overall wage structure and unobserved price effects worked favorably to reduce the gender wage gap. In contrast, the positive gap effect implies that unobserved characteristics or discrimination factors worked unfavorably for female workers. However, its magnitude is much smaller than other factors.

For high-skilled workers, the story is very different. Female high-skilled workers caught up to their male counterparts by improving their human capital over the period. Further, discrimination or gaps in unobserved skills contributed to huge reductions for high-skilled female workers. However, the market premium for skill and experience was quite unfavorable for them, increasing the gender gap. In addition, overall wage inequality deteriorated their wages as they are in a relatively lower position at residual wages.

\section{Concluding Remarks}

We examined the source of changes in the gender wage gap in urban areas of China and India over the past two decades. The evolution of wages in both countries showed common features such as increasing wage inequality and skill premium with the rising supply of skilled workers. In contrast, the changes in the gender wage gaps for each country showed dissimilar patterns over the same time period, as the wage gap deteriorated in China while being dramatically improved in India. 
The decomposition of changes in the gender wage gap showed significant improvement of women's qualifications contributed to gender wage gap reduction in both countries. However, the change in observed prices of skills worked unfavorably for high-skilled women, counterbalancing their improvement in labor market qualifications.

In China, in spite of their fast wage growth, a sharp deterioration of women's position in wage distribution, relative to males after controlling for observed qualifications, contributed significantly to widening gender wage inequality. This gender-specific gap effect is attributable to deterioration in unobservable qualifications of female workers, an increase in discrimination, and less favorable treatment than male workers due to their employment status and industry-specific factors.

The sharp increase in gap effect in China can be found across different skill groups, implying that deterioration of Chinese women's wage is pervasive. One possible driving force behind the increased gap effect would be the decrease in unmeasured qualification of Chinese women. As the Chinese economy grew, household income and housing availability were improved. Therefore, co-residence with parents declined in China. Increasing housework in nuclear family, scarcity of part-time job and decreased social stigma against not working forced women to experience more career-interruption and lower attachment to labor force than before (Maurer-Fazio, Connelly, Chen, and Tang, 2010). Chinese women's weakening attachment to the labor market can lead lower wage and shorter on-the-job training (Barron, Black and Lowenstein 1993). 
Another possibility is the reduction of the state owned sector. More than $97 \%$ of urban workers were still employees in the state sector in 1991, but reduced to 50\% in 2008-2009. Meng (2012) showed that state sector reform has shifted younger, less-educated, and female workers out of the state sector. As state sector workers enjoy wage premium in China, the reform could have caused increasing gender wage gap by disproportionally reallocating male and female workers in the state and private sectors.

By contrast, in India both wage structure and improvement of women's qualifications contributed to a decreased gender wage gap. Women's position in residual wage distribution also improved over the period, reducing the gender wage gap. There must still exist a pervasive discrimination against women originating from social and religious stereotypes on women's role and their status in the Indian society. However, India has shown a remarkable improvement of women's empowerment for last two decades in several dimensions including political representation. In 1993, India implemented constitutional amendment to enact mandated political reservation for women by imposing gender quota (one-third for female) among village councils. The fraction of elected local female leaders rose from less than $5 \%$ in 1992 to over $40 \%$ by 2000 . Beaman et al. (2009) showed that the gender quota for village leadership affected voter's attitudes toward female leaders and weakened stereotypes about gender role in the public and domestic spheres. Beaman et al. (2012) also showed that increased representation of women positively influenced adolescent girls' career aspirations and educational attainment. Our results may imply that women's political empowerment contributed to 
reduced discrimination they face in the labor market as well.

Analyses by skill group showed that there was a race between education and wage structure among high-skilled workers in both countries. The effect of increased skill premium was greater than that of narrowed education gap in China, thereby increasing gender wage differentials. On the other hand, in India the improvement in gender educational gap has a larger effect compared to the relatively slow increase of skill premium in the gap effect, causing the eventual decline in gender wage differentials. However, some studies point out that skill premium has been rising due to structural factors, and thus, by exceeding the speed of narrowing education gap, it can widen gender wage gap. According to Klasen and Pieters (2015), the majority of highly educated women in India worked in public administration, education and health industries in 1987. However, in 2011 many of them were working in financial and business services industries driven by declining share of public sector. As the share of women moving into those sectors increased, the effect of increasing wage inequality on gender wage gap would be greater.

Our data show that the gender gap remains large in both China and India. A significant part of the gender earnings differentials is attributable to the gap in education and skills between males and females.

However, our results also provide important implications that economic development does not guarantee improvement of gender gap in the labor market. The rapid economic development can be 
accompanied with fast increase in inequality which can counterbalance improved education of women. The rapid economic development also does not guarantee improvement of unobserved qualification or decreased discrimination. An important policy priority should be promoting women's empowerment in society in changing common perception of women workers in labor market. Furthermore, our research suggests policies to improve women's unmeasured skill such as college major in STEM area, quality of education, and specific job training, in order to prepare women workers who face with increasing inequality. To conclude, as for the policy implications, China and India should consider specific policies to improve girls' accessibility to higher education, provide vocational and technical training targeted at women, expand flexible work environment with affordable and good-quality child-care facilities, decrease discrimination and increase female empowerment 


\section{References}

Agrawal, T. 2012. "Returns to Education in India: Some Recent Evidence." Journal of Quantitative

Economics 10 (2): 131-51

Barron, J. M., D. A. Black and M. A. Lowenstein. 1993. “Gender Differences in Training, Capital, and Wages." The Journal of Human Resources 28 (2): 343-64.

Beaman, L., R. Chattopadhyay, E. Duflo, R. Pande and P. Topalova. 2009. "Powerful Women: Does

Exposure Reduce Bias?” Quarterly Journal of Economics 124 (4): 1497-1540.

Beaman, L., E. Duflo, R. Pande and P. Topalova. 2012. "Female Leadership Raises Aspirations and

Educational Attainment for Girls: A Policy Experiment in India.” Science 335 (6068): 582-586.

Berman, E., R. Somanathan, and H. Tan. 2005. "Is Skill-Biased Technological Change Here Yet?

Evidence from Indian Manufacturing in the 1990s.” Annals d'Economie et de Statistique 79/80: 299321.

Bhalla, S. S., and R. Kaur. 2011. "Labour Force Participation of Women in India: Some Facts, Some Queries.” Asia Research Centre, London School of Economics and Political Science Working Paper 40. http://eprints.lse.ac.uk/38367

Blau, F. D., and A. H. Beller. 1988. “Trends in Earnings Differentials by Gender, 1971-1981.” ILR Review 41 (4): 513-529. 
Blau, Francine D. and Lawrence M. Kahn. 1997. "Swimming Upstream: Trends in the Gender Wage

Differential in the 1980s." Journal of Labor Economics 15 (1): 1-42.

Blau, F. D., and L. M. Kahn. 2003. "Understanding International Differences in the Gender Pay Gap." Journal of Labor Economics 21 (1): 106-144.

Chamarbagwala, R. 2006. "Economic Liberalization and Wage Inequality in India." World Development 34 (12): 1997-2015.

Datta, N. G., R. L. Oaxaca and N. Smith. 2006. "Swimming Upstream, Floating Downstream: Comparing Women's Relative Wage Progress in the United States and Denmark.” ILR Review 59 (2): $243-266$

Desai, S. B., A. Dubey, B. L. Joshi, M. Sen, A. Shariff, and R. Vanneman. 2010. Human Development in India. New Delhi: Oxford University Press.

Ding, X. H., Q. M. Yu, and H. X. Yu. 2012. "Research on Rates of Return to Education of Chinese Urban Residents and its Changes in this Century." Exploring Education Development 11:1-6.

Ding X., S. Yang, and W. Ha. 2013. "Trends in the Mincerian Rates of Return to Education in Urban China: 1989-2009.” Frontiers of Education in China 8 (3): 378-97.

Fang, H., K. N. Eggleston, J. A. Rizzo, S. Rozelle, and R. J. Zeckhauser. 2012. “The Returns to Education in China: Evidence from the 1986 Compulsory Education Law.” NBER Working Paper 
18189. http://www.nber.org/papers/w18189

Goldin, C. 2014. “A Grand Gender Convergence: Its Last Chapter.” The American Economic Review 104 (4): 1091-1119.

Gustafsson, B., and S. Li. 2000. "Economic Transformation and the Gender Earnings Gap in Urban China." Journal of Population Economics 13: 305-29.

Juhn, C., K. M. Murphy, and B. Pierce. 1991. “Accounting for the Slowdown in Black-White Wage Convergence.” In Workers and Their Wages, edited by Marvin Kosters, 107-43. AEI Press.

Han, J., R. Liu, and J. Zhang. 2012. "Globalization and Wage Inequality: Evidence from Urban China.” Journal of International Economics 87: 288-97.

Heckman, J. J. 1979. “Sample Selection Bias as a Specification Error.” Econometrica 47 (1): 153-161.

Katz, L. F., and K. M. Murphy. 1992. "Changes in Relative Wages, 1963-1987: Supply and Demand Factors." The Quarterly Journal of Economics 107 (1): 35-78.

Kijima, Y. 2006. “Why Did Wage Inequality Increase? Evidence from Urban India 1983-99.” Journal of Development Economics 81: 97-117.

Klasen, S., and J. Pieters. 2015. "What Explains the Stagnation of Female Labor Force Participation in Urban India?" The World Bank Economic Review 29 (3): 449-478. 
Knight, J., and L. Song. 2003 "Increasing Urban Wage Inequality in China.” Economics of Transition 11

(4): 597-619.

Li, S., and S. Ding. 2003. "Long-term Change in Private Returns to Education in Urban China." Social Sciences in China 6: 58-72.

Maurer-Fazio, M., R. Connelly, L. Chen, and L. Tang. 2011. "Childcare, Eldercare, and Labor Force

Participation of Married Women in Urban China, 1982-2000." Journal of Human Resources 46 (2):

261-294

Meng, X. 2012. "Labor Market Outcomes and Reforms in China." The Journal of Economic Perspectives 6 (4): 75-101.

Menon, M., and Y. M. Rodgers. 2008. "International Trade and the Gender Wage Gap: New Evidence from India's Manufacturing Sector." World Development 37 (5): 965-81.

Mehta, A., and R. Hasan. 2012. "Effects of Trade and Services Liberalization on Wage Inequality in India." International Review of Economics and Finance 23: 75-90.

Pande, Rohini, Erin K. Fletcher, and Charity T. Moore. 2015. "Female Labor Force Participation in Asia:

India Country Study.” Forthcoming. Asian Development Bank Working Paper.

Shastry, Gauri Kartini. 2012. "Human Capital Response to Globalization: Education and Information Technology in India.” The Journal of Human Resources. 47(2), pp.287-330 
Xu, B., and W. Li. 2008. "Trade, Technology, and China's Risking Skill Demand.” Economics of Transition 16 (1): 59-84.

Zhang, J., J. Han, P. W. Liu, and Y. Zhao. 2008. "Trends in the Gender Earnings Differential in Urban China, 1988-2004." Industrial and Labor Relations Review 61 (2): 224-243.

Zhang, J., Y. Zhao, A. Park, and X. Song. 2005. "Economic Returns to Schooling in Urban China, 1988 to 2001." Journal of Comparative Economics 33 (4): 730-752.

\footnotetext{
1 The gender wage gap further decreased in rural India and pertinent analyses are in the appendix. We do not have good quality data for rural China.
}

${ }^{2}$ Most existing studies are focused on the United States and find significant convergence in earnings between men and women in recent decades, although there still remains a gender pay gap based on occupation, employment status, and lifetime labor force experience. See Goldin (2014) and studies mentioned therein.

${ }^{3}$ The common set includes the following five provinces: Jiangsu, Anhui, Henan, Hubei, and Guangdong. The major findings from the decomposition technique in Tables 8-11 are robust when we use all 22 provinces in CHIPS data and include the province indicators.

4 We perform the analyses using the sample of rural India and report the results in the appendix.

5 The 170 hours identified is approximately equal to total working hours when an individual works 8 hours a day for 21 days per month. Indeed, many observations report 170 hours for monthly working hours in the survey. 
${ }^{6}$ NSS data contain only information about whether workers worked half day or whole day.

${ }^{7}$ Our results use the conventional measure of experience (age minus years of schooling minus 6). In some waves, the data sets include self-reported experience. When self-reported experience is used, our results are quite robust.

8 See Pande (2015) for an analysis of India's female labor force participation.

${ }^{9}$ In urban India, we add three occupational categories in the regression. We do not include occupation codes for China because of many missing values in earlier data sets. The regression controls province fixed effects in China and state fixed effects in India.

10 Decomposition results by period show a sizable gender wage gap in both the 1990 s and the 2000s, but the effect of an educational gap becomes smaller in the 2000s. This implies that the effects of unobserved skills dominating that of observed skills became more important for the gender wage gap evolution. The estimation results by period are available upon request. 
TABLE 1. OVERVIEW OF REAL WAGE TRENDS

PANEL A. China, 1988-2009

\begin{tabular}{lccc}
\hline & 1988 & 2002 & 2009 \\
\hline Log male real wage & 1.4026 & 2.2589 & 3.0496 \\
\hline Log female real wage & $(0.0061)$ & $(0.0158)$ & $(0.0168)$ \\
\hline Differential & 1.2395 & 2.0094 & 2.7514 \\
& $(0.0066)$ & $(0.0185)$ & $(0.0185)$ \\
\hline Mean female percentile in the male wage distribution & 0.1631 & 0.2495 & 0.2982 \\
\hline Ratio of average real wages between male and female & $(0.0090)$ & $(0.0243)$ & $(0.0255)$ \\
\hline Sample size & 42.21 & 41.67 & 38.09 \\
\hline
\end{tabular}

PANEL B. India, 1988-2010

\begin{tabular}{lccc}
\hline & 1988 & 2000 & 2010 \\
\hline Log male real wage & 1.7371 & 2.1171 & 2.2800 \\
\hline Log female real wage & $(0.0100)$ & $(0.0135)$ & $(0.0159)$ \\
\hline Differential & 1.1471 & 1.6394 & 1.8983 \\
& $(0.0257)$ & $(0.0293)$ & $(0.0362)$ \\
\hline Mean female percentile in the male wage distribution & 0.5900 & 0.4777 & 0.3817 \\
\hline Ratio of average real wages between male and female & $(0.0234)$ & $(0.0255)$ & $(0.0330)$ \\
\hline Sample size & 32.83 & 36.75 & 39.51 \\
\hline
\end{tabular}

Notes: Sample consists of full-time paid workers between ages 18 and 60 in both countries. Mean female percentile in the male wage distribution was computed by assigning each woman a percentile ranking in the indicated years' male wage distribution and calculating the female mean of these percentiles. 
TABLE 2. SELECTION-CORRECTED GENDER WAGE GAP: HECKMAN'S TWO-STAGE ESTIMATION

\begin{tabular}{|c|c|c|c|}
\hline Year & OLS & Two-Step & Bias \\
\hline \multicolumn{4}{|c|}{ PANEL A. Urban China } \\
\hline 1988 & -0.1045 & -0.1324 & 0.0279 \\
\hline 2002 & -0.1813 & -0.1352 & -0.0461 \\
\hline 2009 & -0.2718 & -0.2573 & -0.0145 \\
\hline \multicolumn{4}{|c|}{ PANEL B. Urban India } \\
\hline 1988 & -0.4810 & -0.2186 & -0.2624 \\
\hline 2000 & -0.3339 & -0.1712 & -0.1627 \\
\hline 2010 & -0.3477 & -0.0266 & -0.3211 \\
\hline
\end{tabular}

Notes: Regression sample includes urban women between the ages of 18 and 60. The set of selection variables includes number of children under 6, number of children under 18, and marital status. The selection equation of urban China in 1988 does not contain marital status because of data limitations. 


\section{TABLE 3. SELECTION-CORRECTED GENDER WAGE GAP: SELECTION CONTROL}

\begin{tabular}{lccc}
\hline \multicolumn{5}{c}{ PANEL A. Urban China } \\
\hline Year & 1988 & 2002 & 2009 \\
\hline Excluding the least likely to work (Prob.<0.05) & -0.1041 & -0.1854 & -0.2710 \\
\hline Excluding the least likely to work (Prob.<0.1) & -0.1041 & -0.1854 & -0.2706 \\
\hline Rule 2 + using only married women & $-0.0891^{*}$ & -0.1734 & -0.2541 \\
\hline \multicolumn{2}{c}{ PANEL B. Urban India } & & \\
\hline Year & 1988 & 2000 & 2010 \\
\hline Excluding the least likely to work (Prob.<0.05) & -0.4810 & -0.3997 & -0.3714 \\
\hline Excluding the least likely to work (Prob.<0.1) & -0.4953 & -0.4141 & -0.3765 \\
\hline Rule 2 + using only married women & -0.4894 & -0.4035 & -0.4071 \\
\hline
\end{tabular}

Notes: All estimated gender gap model controls years of schooling, experience, and square term of experience.

*Estimates in this case are from a sample of 1995, as CHIPS data in 1988 does not contain marital status. 
TABLE 4. CHANGES IN REAL MONTHLY WAGES AMONG FULL-TIME URBAN WORKERS IN CHINA

\begin{tabular}{|c|c|c|c|}
\hline Group & 1988-2009 & 1988-2002 & 2002-2009 \\
\hline All & 141.9 & 71.2 & 70.7 \\
\hline \multicolumn{4}{|l|}{ By gender } \\
\hline Male & 150.4 & 77.9 & 72.5 \\
\hline Female & 131.3 & 63.2 & 68.1 \\
\hline \multicolumn{4}{|l|}{ By education } \\
\hline Elementary school & 119.3 & 48.2 & 71.0 \\
\hline Junior high school & 126.7 & 53.7 & 73.0 \\
\hline Senior high school & 136.0 & 71.0 & 65.1 \\
\hline University degree or above & 171.5 & 93.7 & 77.8 \\
\hline \multicolumn{4}{|l|}{ By experience } \\
\hline $1-10$ years & 169.4 & 83.0 & 86.4 \\
\hline $11-20$ years & 154.4 & 73.2 & 81.2 \\
\hline $21-30$ years & 125.0 & 64.4 & 60.6 \\
\hline$>30$ years & 119.2 & 66.6 & 52.5 \\
\hline \multicolumn{4}{|l|}{ Male workers by education } \\
\hline Elementary school & 119.4 & 67.5 & 51.9 \\
\hline Junior high school & 132.2 & 61.9 & 70.3 \\
\hline Senior high school & 146.1 & 74.0 & 72.1 \\
\hline University degree or above & 177.4 & 98.2 & 79.2 \\
\hline \multicolumn{4}{|l|}{ Female Workers by Education } \\
\hline Elementary school & 118.1 & 40.4 & 77.7 \\
\hline Junior high school & 120.5 & 44.4 & 76.0 \\
\hline Senior high school & 124.6 & 67.5 & 57.1 \\
\hline University degree or above & 161.6 & 86.2 & 75.4 \\
\hline \multicolumn{4}{|l|}{ Male workers by experience } \\
\hline $1-10$ years & 175.9 & 90.0 & 85.9 \\
\hline $11-20$ years & 170.3 & 82.9 & 87.4 \\
\hline $21-30$ years & 136.6 & 72.0 & 64.6 \\
\hline$>30$ years & 122.9 & 69.9 & 53.0 \\
\hline \multicolumn{4}{|l|}{ Female Workers by Experience } \\
\hline $1-10$ years & 163.0 & 76.0 & 86.9 \\
\hline $11-20$ years & 137.0 & 62.5 & 74.5 \\
\hline $21-30$ years & 112.0 & 56.8 & 55.2 \\
\hline$>30$ years & 110.0 & 58.6 & 51.3 \\
\hline
\end{tabular}


Notes: Annual average monthly wages were computed for each of 32 gender-education-experience cells. Average wages for broader groups in each year are computed based on these cell averages using the average employment share per cell for the entire period as weights. All wages are deflated by the consumer price index. 
TABLE 5. CHANGES IN REAL MONTHLY SUPPLY IN URBAN CHINA

\begin{tabular}{|c|c|c|c|}
\hline Group & 1988-2009 & 1988-2002 & 2002-2009 \\
\hline \multicolumn{4}{|l|}{ By gender } \\
\hline Male & 6.8 & 4.1 & 2.7 \\
\hline Female & -10.5 & -6.2 & -4.3 \\
\hline \multicolumn{4}{|l|}{ By education } \\
\hline Elementary school & -159.9 & -153.6 & -6.3 \\
\hline Junior high school & -83.0 & -55.9 & -27.1 \\
\hline Senior high school & -6.3 & 10.8 & -17.1 \\
\hline University degree or above & 106.2 & 79.0 & 27.2 \\
\hline \multicolumn{4}{|l|}{ By experience } \\
\hline $1-10$ years & -8.8 & -43.8 & 35.0 \\
\hline $11-20$ years & 2.5 & 7.7 & -5.2 \\
\hline $21-30$ years & 6.7 & 16.2 & -9.5 \\
\hline$>30$ years & -6.3 & -2.6 & -3.6 \\
\hline \multicolumn{4}{|l|}{ Male workers by education } \\
\hline Elementary school & -136.4 & -131.1 & -5.4 \\
\hline Junior high school & -74.6 & -47.1 & -27.5 \\
\hline Senior high school & 5.2 & 10.5 & -5.3 \\
\hline University degree or above & 90.7 & 68.6 & 22.1 \\
\hline \multicolumn{4}{|l|}{ Female workers by education } \\
\hline Elementary school & -187.6 & -179.9 & -7.7 \\
\hline Junior high school & -96.1 & -69.8 & -26.3 \\
\hline Senior high school & -23.1 & 11.2 & -34.3 \\
\hline University degree or above & 139.2 & 102.9 & 36.3 \\
\hline \multicolumn{4}{|l|}{ Male workers by experience } \\
\hline $1-10$ years & -10.6 & -47.4 & 36.8 \\
\hline $11-20$ years & 13.2 & 12.7 & 0.4 \\
\hline $21-30$ years & 10.6 & 18.9 & -8.2 \\
\hline$>30$ years & 6.5 & 4.8 & 1.7 \\
\hline \multicolumn{4}{|l|}{ Female workers by experience } \\
\hline $1-10$ years & -6.9 & -39.9 & 33.0 \\
\hline $11-20$ years & -12.8 & 0.9 & -13.7 \\
\hline $21-30$ years & 1.3 & 12.5 & -11.2 \\
\hline$>30$ years & -48.7 & -24.4 & -24.3 \\
\hline
\end{tabular}

Notes: The numbers in the table represent log changes in each group's share of total monthly labor supply measured in 
efficiency units (annual working hours times the average relative wage of the group for the sample period) using CHIPS. Supply measures include all workers in the count sample described above. 
TABLE 6. CHANGES IN REAL WEEKLY WAGES AMONG FULL-TIME URBAN WORKERS IN INDIA

\begin{tabular}{|c|c|c|c|c|}
\hline Group & $1988-2010$ & $1988-2000$ & 2000-2005 & 2005-2010 \\
\hline All & 37.76 & 30.74 & -5.99 & 13.01 \\
\hline \multicolumn{5}{|l|}{ By gender } \\
\hline Male & 36.93 & 30.08 & -5.04 & 11.88 \\
\hline Female & 41.87 & 34.01 & -10.71 & 18.57 \\
\hline \multicolumn{5}{|l|}{ By education } \\
\hline Illiterate & 41.26 & 29.25 & 1.89 & 10.12 \\
\hline Literate or primary school & 28.92 & 29.43 & -1.16 & 0.66 \\
\hline Secondary school & 27.58 & 27.82 & -13.43 & 13.20 \\
\hline University degree or above & 60.92 & 38.29 & -4.32 & 26.95 \\
\hline \multicolumn{5}{|l|}{ By experience } \\
\hline $1-10$ years & 43.48 & 25.73 & -7.48 & 25.23 \\
\hline $11-20$ years & 38.36 & 30.96 & -8.89 & 16.30 \\
\hline $21-30$ years & 34.76 & 32.10 & -4.07 & 6.73 \\
\hline$>30$ years & 34.65 & 33.86 & -2.94 & 3.72 \\
\hline \multicolumn{5}{|l|}{ Male workers by education } \\
\hline Illiterate & 36.73 & 25.46 & 5.34 & 5.93 \\
\hline Literate or primary school & 26.78 & 27.32 & 0.07 & -0.61 \\
\hline Secondary school & 29.53 & 28.25 & -11.30 & 12.58 \\
\hline University degree or above & 60.90 & 39.15 & -4.96 & 26.71 \\
\hline \multicolumn{5}{|l|}{ Female workers by education } \\
\hline Illiterate & 49.29 & 35.97 & -4.23 & 17.55 \\
\hline Literate or primary school & 42.12 & 42.44 & -8.79 & 8.47 \\
\hline Secondary school & 8.96 & 23.65 & -33.80 & 19.11 \\
\hline University degree or above & 61.06 & 33.89 & -1.00 & 28.17 \\
\hline \multicolumn{5}{|l|}{ Male workers by experience } \\
\hline $1-10$ years & 44.08 & 25.61 & -6.29 & 23.77 \\
\hline $11-20$ years & 38.07 & 30.03 & -7.54 & 15.58 \\
\hline $21-30$ years & 33.12 & 30.38 & -3.75 & 6.48 \\
\hline > 30 years & 32.00 & 33.49 & -1.69 & 0.20 \\
\hline \multicolumn{5}{|l|}{ Female Workers by Experience } \\
\hline $1-10$ years & 39.90 & 20.48 & -14.63 & 34.04 \\
\hline $11-20$ years & 40.10 & 36.59 & -17.14 & 20.65 \\
\hline $21-30$ years & 42.62 & 40.34 & -5.64 & 7.92 \\
\hline
\end{tabular}




\begin{tabular}{lcccc}
\hline Group & $1988-2010$ & $1988-2000$ & $2000-2005$ & $2005-2010$ \\
\hline$>30$ years & 43.89 & 35.16 & -7.30 & 16.02 \\
\hline
\end{tabular}

Notes: Annual average weekly wages were computed for each of 32 gender-education-experience cells. Average wages for broader groups in each year are computed based on these cell averages using the average employment share per cell for the entire period as weights. All wages are deflated by the consumer price index each year. 
TABLE 7. CHANGES IN REAL WEEKLY SUPPLY OF EMPLOYED URBAN WORKERS IN INDIA

\begin{tabular}{|c|c|c|c|c|}
\hline Group & 1988-2010 & $1988-2000$ & 2000-2005 & 2005-2010 \\
\hline \multicolumn{5}{|l|}{ By gender } \\
\hline Male & -1.80 & -0.37 & -2.09 & 0.66 \\
\hline Female & 13.32 & 2.92 & 14.85 & -4.45 \\
\hline \multicolumn{5}{|l|}{ By education } \\
\hline Illiterate & -89.23 & -38.84 & -35.05 & -15.35 \\
\hline Literate or primary school & -77.06 & -47.88 & -10.93 & -18.25 \\
\hline Secondary school & -0.42 & 6.18 & -42.10 & 35.51 \\
\hline University degree or above & 55.78 & 32.07 & 41.00 & -17.30 \\
\hline \multicolumn{5}{|l|}{ By experience } \\
\hline $1-10$ years & 11.76 & -1.38 & 20.16 & -7.02 \\
\hline $11-20$ years & -6.63 & -3.26 & -3.80 & 0.42 \\
\hline $21-30$ years & 5.92 & 12.13 & -6.98 & 0.77 \\
\hline$>30$ years & -7.42 & -8.89 & -3.31 & 4.78 \\
\hline \multicolumn{5}{|l|}{ Male workers by education } \\
\hline Illiterate & -86.85 & -37.68 & -40.03 & -9.15 \\
\hline Literate or primary school & -81.57 & -49.49 & -13.17 & -18.91 \\
\hline Secondary school & -1.69 & 5.14 & -42.85 & 36.02 \\
\hline University degree or above & 53.69 & 32.51 & 39.91 & -18.73 \\
\hline \multicolumn{5}{|l|}{ Female workers by education } \\
\hline Illiterate & -97.21 & -42.62 & -19.92 & -34.67 \\
\hline Literate or primary school & -27.67 & -27.07 & 11.83 & -12.44 \\
\hline Secondary school & 15.43 & 19.23 & -33.68 & 29.88 \\
\hline University degree or above & 67.65 & 29.37 & 47.60 & -9.32 \\
\hline \multicolumn{5}{|l|}{ Male workers by experience } \\
\hline $1-10$ years & 5.02 & -1.92 & 16.85 & -9.90 \\
\hline $11-20$ years & -8.03 & -4.55 & -5.87 & 2.39 \\
\hline $21-30$ years & 5.48 & 12.16 & -8.48 & 1.79 \\
\hline$>30$ years & -7.03 & -8.52 & -4.28 & 5.77 \\
\hline \multicolumn{5}{|l|}{ Female Workers by Experience } \\
\hline $1-10$ years & 44.82 & 1.81 & 37.47 & 5.54 \\
\hline $11-20$ years & 5.70 & 8.17 & 11.96 & -14.43 \\
\hline $21-30$ years & 9.55 & 11.86 & 4.82 & -7.13 \\
\hline$>30$ years & -10.51 & -11.81 & 4.25 & -2.96 \\
\hline
\end{tabular}

Notes: The numbers in the table represent log changes in each group's share of total monthly labor supply measured in 
efficiency units (annual working hours times the average relative wage of the group for the sample period) using CHIPS. Supply measures include all workers in the count sample described above. 
TABLE 8. DECOMPOSITION OF CHANGES IN THE GENDER WAGE GAP: HUMAN CAPITAL MODEL

\begin{tabular}{|l|c|c|}
\hline & $\begin{array}{c}(1) \\
\text { Urban China }\end{array}$ & $\begin{array}{c}(2) \\
\text { Urban India }\end{array}$ \\
\hline A. Descriptive Statistics & & \\
\hline Mean female residual from male wage regression & & \\
\hline 1988 & -0.1101 & -0.4888 \\
\hline 2010 (2009 for urban China) & -0.2713 & -0.3768 \\
\hline Mean female residual percentile & & \\
\hline 1988 & 45.48 & 30.21 \\
\hline 2010 (2009 for urban China) & 38.49 & 35.80 \\
\hline B. Decomposition of Change & & \\
\hline Change in differential (D2010-D1988) & 0.1351 & -0.2082 \\
\hline All observed X's & -0.0254 & -0.0625 \\
\hline Education variables & -0.0342 & -0.0745 \\
\hline Experience variables & 0.0088 & 0.0120 \\
\hline All observed prices & 0.0012 & -0.0336 \\
\hline Education variables & 0.0312 & -0.0315 \\
\hline Experience variables & -0.0300 & -0.0021 \\
\hline Gap effect & 0.2388 & -0.1295 \\
\hline Unobserved prices & -0.0776 & 0.0175 \\
\hline Sum gender-specific & 0.2134 & -0.1920 \\
\hline Sum wage structure & -0.0764 & -0.0161 \\
\hline
\end{tabular}


TABLE 9. DECOMPOSITION OF CHANGES IN THE GENDER WAGE GAP: FULL MODEL

(1)

Urban China
(2)

Urban India

Period

1988-2009

1988-2010

\begin{tabular}{|c|c|c|}
\hline \multicolumn{3}{|c|}{ Mean female residual from male wage regression } \\
\hline Year 0 & -0.1047 & -04921 \\
\hline Year 1 & -0.2416 & -0.4814 \\
\hline \multicolumn{3}{|l|}{ Mean female residual percentile } \\
\hline Year 0 & 44.35 & 28.81 \\
\hline Year 1 & 38.29 & 31.58 \\
\hline \multicolumn{3}{|l|}{ B. Decomposition of Change } \\
\hline Change in differential (D2010-D1988) & 0.1351 & -0.2082 \\
\hline Observed X's & -0.0204 & -0.0522 \\
\hline Education variables & -0.0336 & -0.0507 \\
\hline Experience variables & 0.0099 & 0.0103 \\
\hline Industry variables & -0.0013 & -0.0304 \\
\hline Province (State) indicators & 0.0046 & 0.0086 \\
\hline Occupation & & 0.0103 \\
\hline Observed prices & 0.0177 & -0.1441 \\
\hline Education variables & 0.0278 & -0.0405 \\
\hline Experience variables & -0.0290 & 0.0012 \\
\hline Industry variables & 0.0179 & -0.0376 \\
\hline Province (State) indicators & 0.0010 & -0.0308 \\
\hline Occupation & & -0.0362 \\
\hline Gap Effect & 0.1089 & -0.0191 \\
\hline Unobserved prices & 0.0290 & 0.0085 \\
\hline Sum gender-specific & 0.0885 & -0.0713 \\
\hline Sum wage structure & 0.0467 & -0.1356 \\
\hline
\end{tabular}


TABLE 10. DECOMPOSITION OF CHANGES IN THE GENDER PAY WAGE BY SKILL LEVEL: URBAN CHINA

\begin{tabular}{|l|c|c|c|}
\hline & Low-Skilled & Medium-Skilled & High-Skilled \\
\hline A. Descriptive Statistics & & & \\
\hline Mean log wage of male & & & \\
\hline 1988 & 1.0980 & 1.4791 & 1.5882 \\
\hline 2009 & 2.8217 & 2.9752 & 3.2025 \\
\hline Mean log wage of female & & & \\
\hline 1988 & 0.9775 & 1.3049 & 1.3983 \\
\hline 2009 & 2.6022 & 2.6804 & 2.8233 \\
\hline Mean female residual from male wage regression & & & \\
\hline 1988 & -0.0649 & -0.1319 & -0.1346 \\
\hline 2009 & -0.2515 & -0.2843 & -0.2301 \\
\hline Mean female residual percentile & & & \\
\hline 1988 & 49.17 & 40.57 & 42.71 \\
\hline 2009 & 37.32 & 36.07 & 68.57 \\
\hline B. Decomposition of Change & & & \\
\hline Change in differential (D2009-D1988) & 0.0990 & 0.1206 & 0.1893 \\
\hline Observed X's & -0.0932 & 0.0305 & -0.2623 \\
\hline Observed prices & 0.0052 & -0.0632 & 0.3589 \\
\hline Gap effect & 0.2651 & 0.1914 & 0.1612 \\
\hline Unobserved prices & -0.0785 & -0.0389 & -0.0657 \\
\hline Sum gender-specific & 0.1719 & 0.2219 & -0.1011 \\
\hline Sum wage structure & & -0.1021 & 0.2932 \\
\hline
\end{tabular}


TABLE 11. DECOMPOSITION OF CHANGES IN THE GENDER PAY WAGE BY SKILL LEVEL: URBAN INDIA

\begin{tabular}{|l|l|l|l|}
\hline & Low-Skilled & Medium-Skilled & High-Skilled \\
\hline A. Descriptive Statistics & & & \\
\hline Mean log wage of male & & & \\
\hline 1988 & 1.1277 & 1.6292 & 2.2812 \\
\hline 2010 & 1.4267 & 1.7631 & 2.7340 \\
\hline Mean log wage of female & & & \\
\hline 1988 & 0.3872 & 0.4592 & 1.3387 \\
\hline 2010 & 0.8819 & 1.1855 & 2.2770 \\
\hline Mean female residual from male wage regression & & & \\
\hline 1988 & -0.3015 & -0.5490 & -0.6895 \\
\hline 2010 & -0.3264 & -0.4910 & -0.3912 \\
\hline Mean female residual percentile & & & \\
\hline 1988 & 30.81 & 22.22 & 25.15 \\
\hline 2010 & 28.47 & 26.54 & 36.61 \\
\hline B. Decomposition of Change & & & \\
\hline Change in differential (D2010-D1988) & -0.1966 & -0.5925 & -0.4855 \\
\hline Observed X's & -0.1823 & -0.2946 & -0.5288 \\
\hline Observed prices & -0.0403 & -0.2392 & 0.3445 \\
\hline Gap effect & 0.0589 & 0.0479 & -0.3366 \\
\hline Unobserved prices & -0.0340 & -0.1059 & 0.0384 \\
\hline Sum gender-specific & -0.1234 & -0.2467 & -0.8654 \\
\hline Sum wage structure & -0.0743 & -0.3451 & 0.3829 \\
\hline
\end{tabular}


PANEL A. China

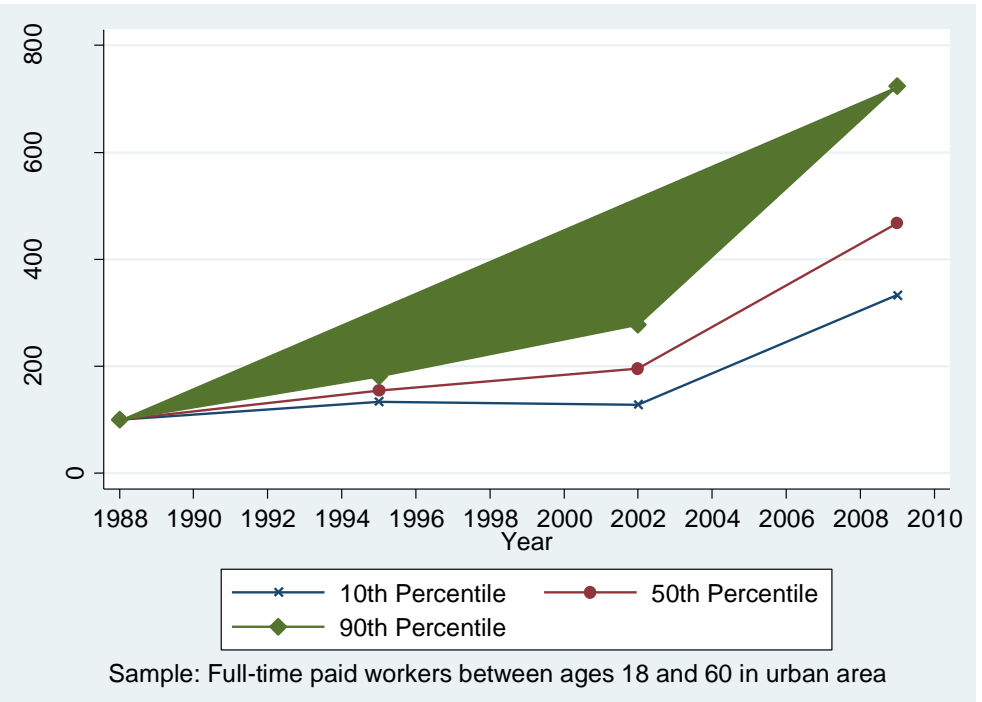

PANEL B. India

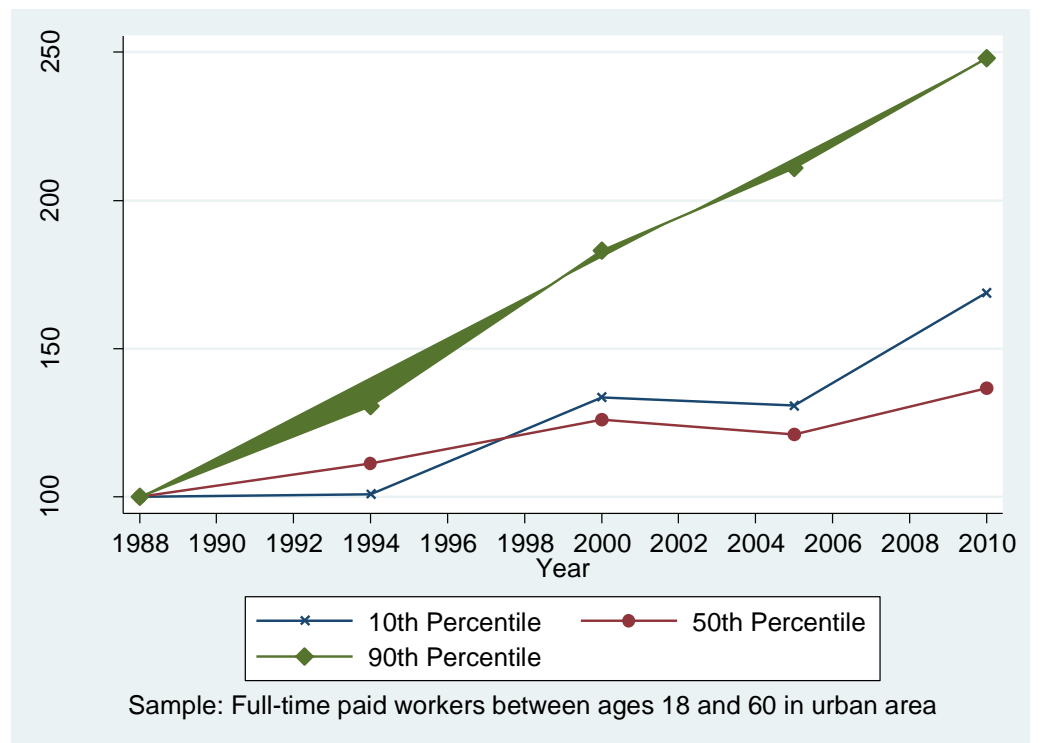

FIGURE 1. INDEXED WAGE INEQUALITY 
PANEL A. China

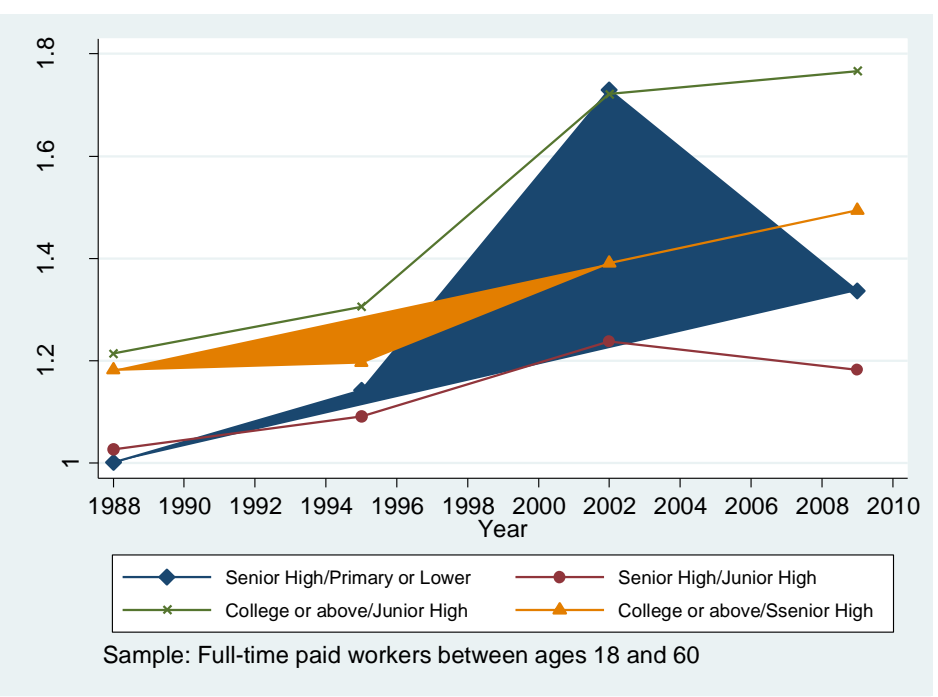

PANEL B. India

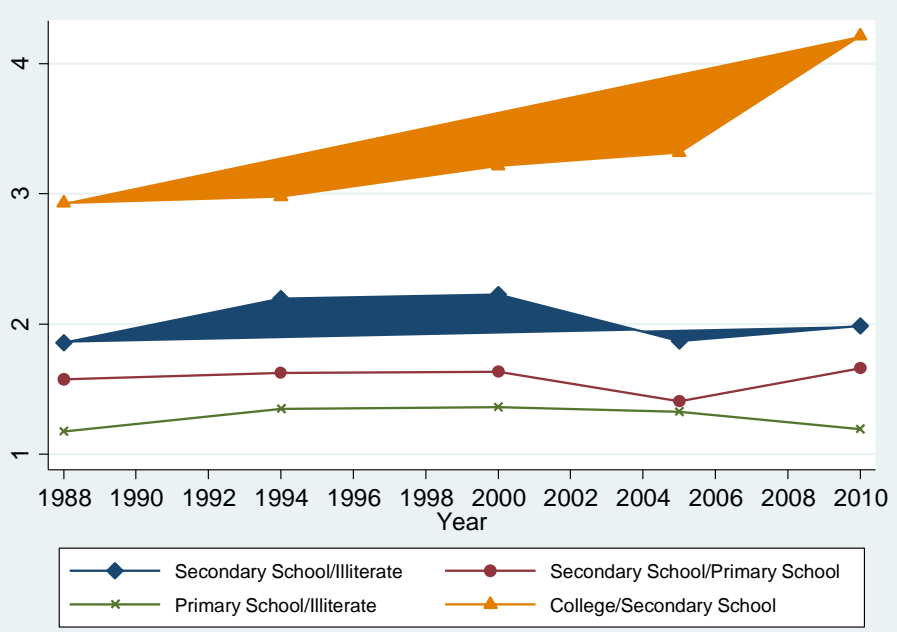

Sample: Full-time paid workers between ages 18 and 60

FIGURE 2. TRENDS IN SKILL PREMIUM 
PANEL A. China

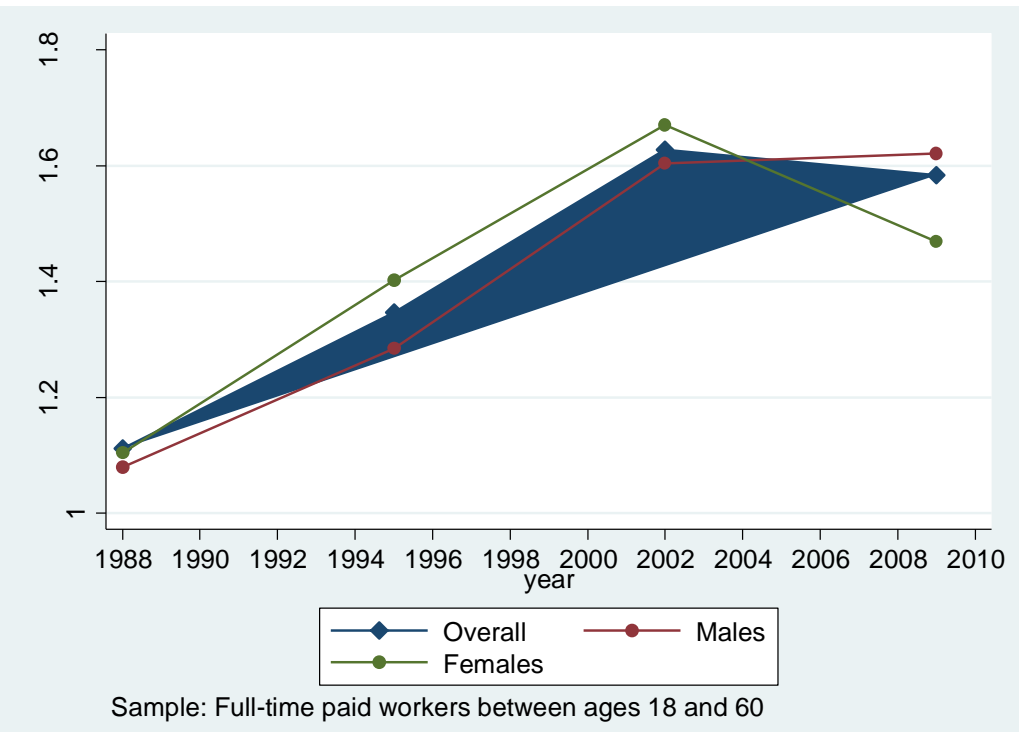

PANEL B. India

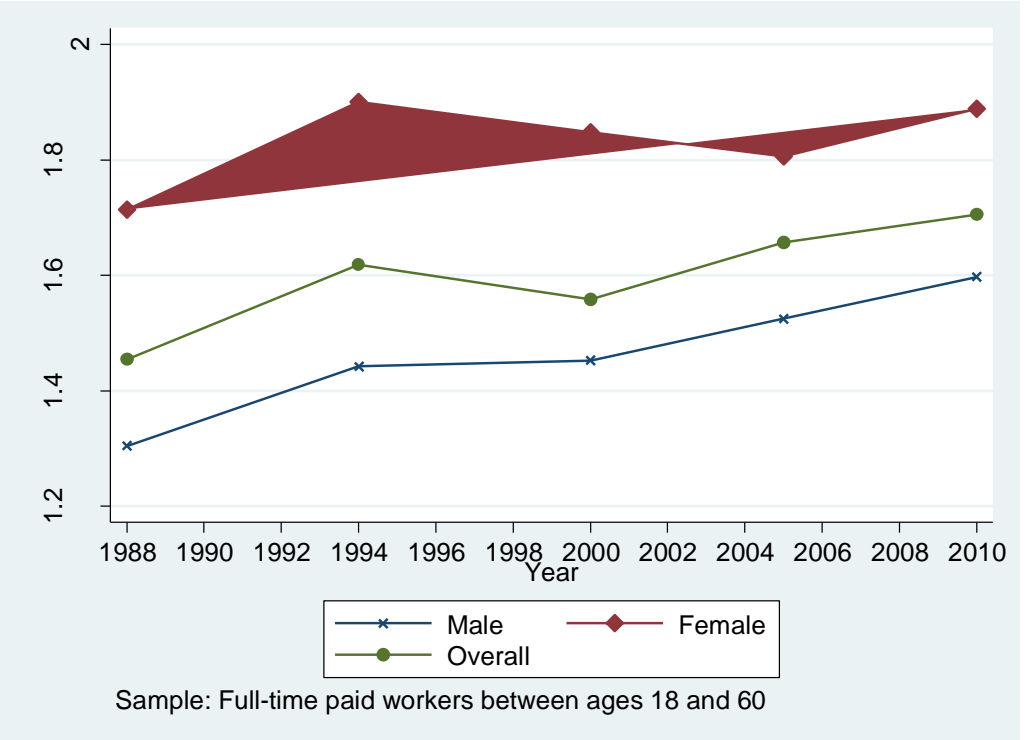

FIGURE 3. RESIDUAL INEQUALITY 
PANEL A. China

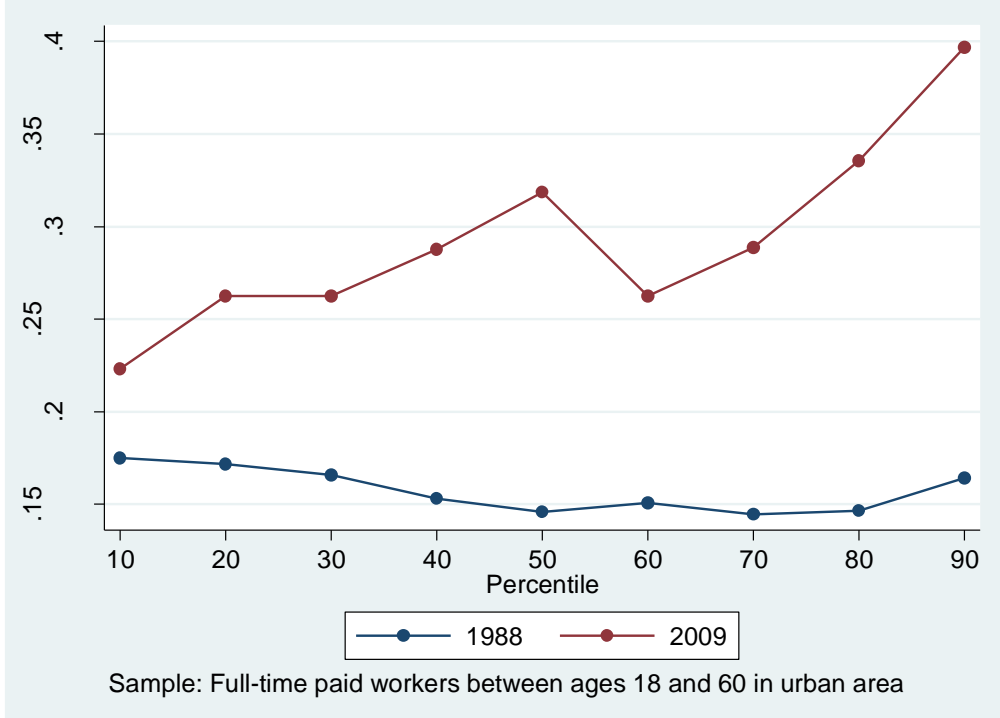

PANEL B. India

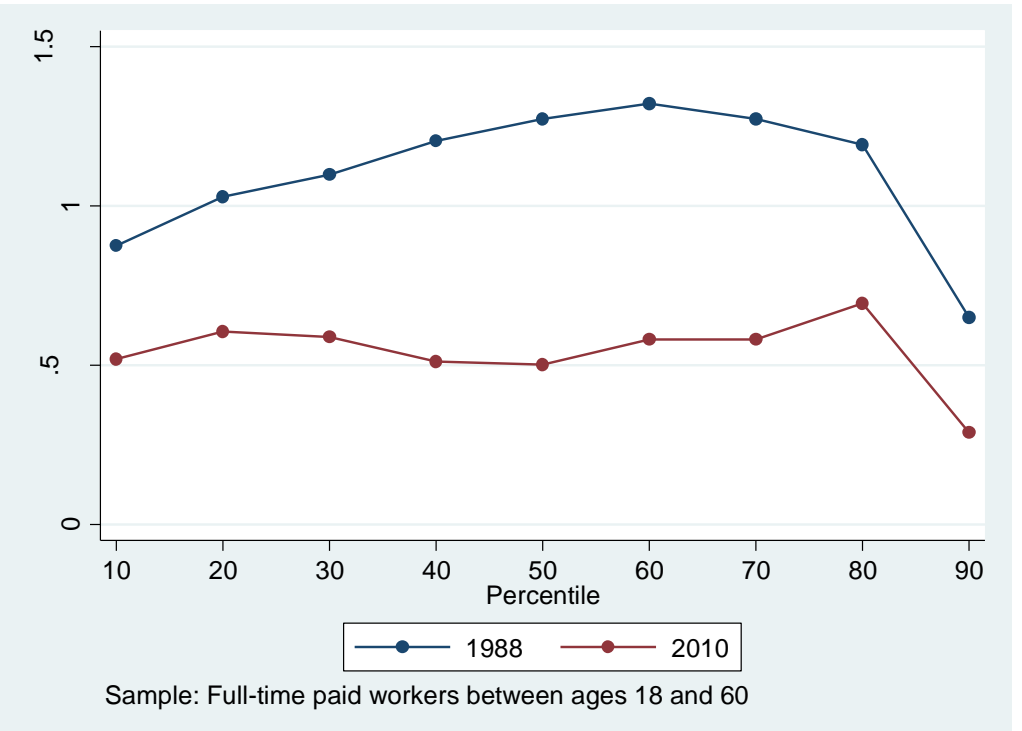

FIGURE 4. GENDER LOG WAGE GAP 
PANEL A. China

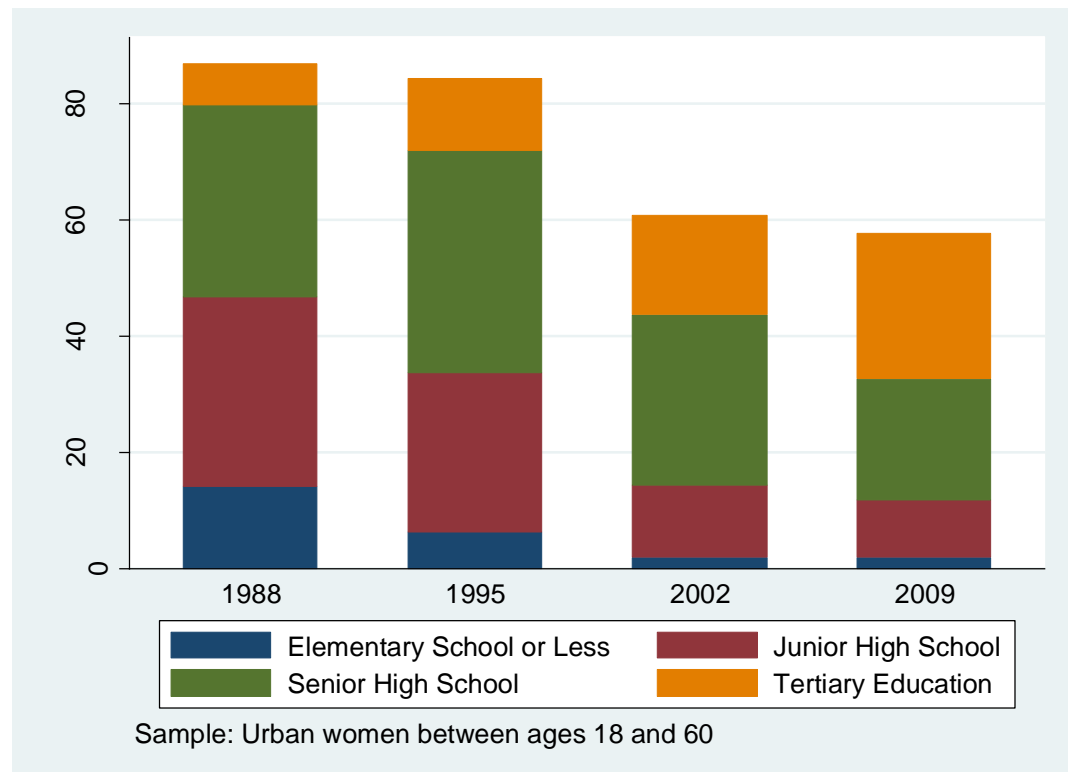

PANEL B. India

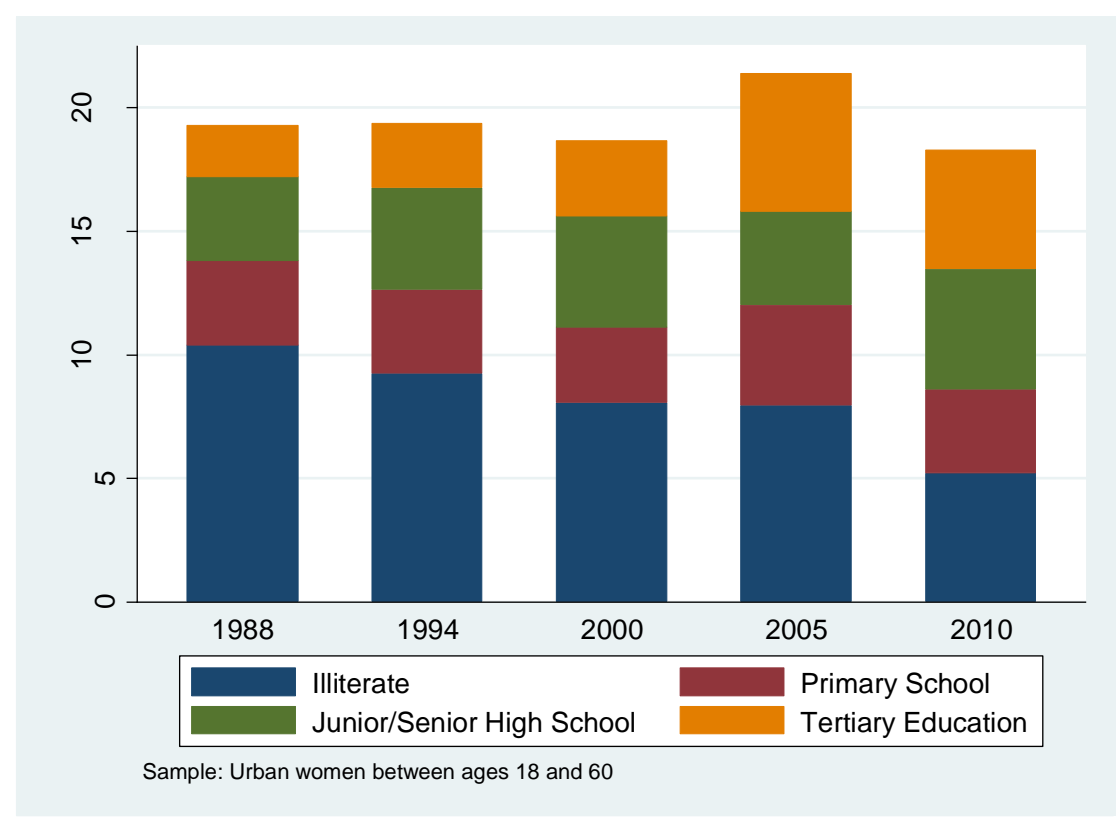

FIGURE 5. FEMALE LABOR FORCE PARTICIPATION RATE 


\section{FOR ONLINE PUBLICATION ONLY}

\section{Appendix}

\section{Analyses of Rural India}

This appendix summarizes wage inequality changes and gender earnings differentials in rural India during the 1990s and 2000s. Figure A1 shows that real wages among the skilled group (the 90th percentile) decreased in the 2000 s while they rose among the low-skilled and median groups, implying that wage inequality declined in the recent decade. Figure A2 shows that all indicators of skill premiums declined over the period. An exception is the rise of the premium for workers with tertiary education relative to secondary educated workers in the 1990s.

\section{$<$ Figures A1\& A2 Here>}

Figure A3 also indicates that the residual wage differential between the 90th and 10th percentiles for all workers declined in the 1990s, indicating the declining trends of wage inequality among narrowly defined demographic groups. The wage differential showed an increasing trend for rural males in the 2000s. While the gap increased, the wage differentials for males remained below that for female workers over the period.

\section{$<$ Figure A3 Here >}

Table A1 shows trends in male and female wages for the past two decades in rural India. Women's relative wages improved significantly. The average female wage increased from about 42 percent in 1988 to about 61 percent of the average male wage in 2010. Mean female wage percentile in the male wage distribution rose from 15.6 to 27.1. Figure A4 shows the gender gap in log weekly earnings declined in all percentiles in wage distribution.

<Table A1 Here>

$<$ Figure A4 Here> 
Figure A5 shows a slight decrease in female workers' labor market participation rate over the period, implying the selection into the labor force could be associated with changes in the gender wage gap. Table A2 presents OLS estimates and two-step estimates of the gender wage gap for 1988, 2000, and 2010. The result shows that there is significant negative selection into the labor market. After correcting selection bias, the gender wage gap becomes smaller but still shows declining trends over time. We also adopted alternative specifications, which were applied to the analysis of urban India, to further examine the robustness of the estimated change of the gender gap. The results also support a decrease in the gender wage gap even after selectivity correction.

\section{$<$ Figure A5 Here>}

$<$ Table A2 Here>

Table A3 presents the estimation results of decomposition of change in gender wage differentials in rural India using both the human capital model and full model. In the human capital model, the negative price effect indicates that observed price change was favorable to rural female workers, just as with females working in the urban area (Table 8). Its magnitude is much greater in rural than in urban areas indicating that the favorable wage structure had a greater contribution in rural areas where more workers are low- and medium-skilled. The magnitude of the effect of observed qualifications contributing to a decreased gender wage differential is also greater in rural area as many female workers in the 1980 s were less educated in rural than in urban areas.

\section{<Table A3 Here>}

The unobserved parts contributed significantly to reduction of the gender wage gap. The negative estimate of gap effect indicates that women's position in residual distribution improved over the period in rural India. However, the contribution of the gap effect is relatively small compared to that 
in urban areas. The estimated unobserved price effect is negative in rural areas, implying that being in a relatively unfavorable position did not cause as much wage loss in 2010 compared to 1988.

In the full model, the results are similar with those in the human capital model. However, the size of change in overall wage inequality became much smaller in the full model, indicating that industry and state wage differentials constituted a great part of the effects of observed qualifications and observed prices.

The size of the gap effect in the full model declined more significantly compared to that in the human capital model. The estimate of the gap effect has a positive sign. The striking difference implies that relative improvement in women's position in residual distribution was mainly caused by the inflow of female workers into better-treated industries and regions. On the other hand, the estimate of unobserved prices does not show the magnitude of difference from those in the human capital model. 
TABLE A1. OVERVIEW OF REAL WAGE TRENDS IN RURAL INDIA, 1988-2010

\begin{tabular}{lccc}
\hline & 1988 & 2000 & 2010 \\
\hline Log male real wage & 1.3744 & 1.4095 & 1.5955 \\
& $(0.0236)$ & $(0.0108)$ & $(0.0100)$ \\
\hline Log female real wage & 0.3718 & 0.7978 & 1.0991 \\
\hline Differential & $(0.0115)$ & $(0.0123)$ & $(0.0169)$ \\
\hline Mean female percentile in the male wage distribution & 1.0025 & 0.6117 & 0.4964 \\
\hline Ratio of average real wages between male and female & $(0.0251)$ & $(0.0130)$ & $(0.0174)$ \\
\hline
\end{tabular}

Note: Mean female percentile in the male wage distribution was computed by assigning each woman a percentile ranking in the indicated years male wage distribution and calculating the female mean of these percentiles. 
TABLE A2. SELECTION-CORRECTED GENDER WAGE GAP IN RURAL INDIA: HECKMAN'S TWO-STAGE ESTIMATION

\begin{tabular}{cccc}
\hline Year & OLS & Two-Step & Bias \\
\hline 1988 & -0.6180 & -0.2423 & -0.3757 \\
\hline 2000 & -0.4006 & -0.2226 & -0.1780 \\
\hline 2010 & -0.4351 & -0.1113 & -0.3238 \\
\hline
\end{tabular}




\section{TABLE A3. DECOMPOSITION OF CHANGES IN THE GENDER WAGE GAP IN RURAL INDIA}

\begin{tabular}{|c|c|c|}
\hline & $\begin{array}{c}\text { Human Capital } \\
\text { Model }\end{array}$ & Full Model \\
\hline \multicolumn{3}{|l|}{ A. Descriptive Statistics } \\
\hline \multicolumn{3}{|c|}{ Mean female residual from male wage regression } \\
\hline 1988 & -0.5965 & -0.4937 \\
\hline 2010 (2009 for urban China) & -0.4226 & -0.4468 \\
\hline \multicolumn{3}{|l|}{ Mean female residual percentile } \\
\hline 1988 & 21.79 & 24.18 \\
\hline 2010 (2009 for urban China) & 28.28 & 26.98 \\
\hline \multicolumn{3}{|l|}{ B. Decomposition of Change } \\
\hline Change in differential (D2010-D1988) & -0.5044 & -0.5044 \\
\hline All observed X's & -0.1592 & -0.2019 \\
\hline Education variables & -0.1707 & -0.0923 \\
\hline Experience variables & 0.0115 & 0.0092 \\
\hline Industry indicators & & -0.2084 \\
\hline State indicators & & 0.0896 \\
\hline All observed prices & -0.1719 & -0.2562 \\
\hline Education variables & -0.1865 & -0.1573 \\
\hline Experience variables & 0.0146 & 0.0220 \\
\hline Industry indicators & & -0.0161 \\
\hline State indicators & & -0.1048 \\
\hline Gap effect & -0.0768 & 0.0406 \\
\hline Unobserved prices & -0.0971 & -0.0876 \\
\hline Sum gender-specific & -0.2360 & -0.1613 \\
\hline Sum wage structure & -0.2690 & -0.3488 \\
\hline
\end{tabular}




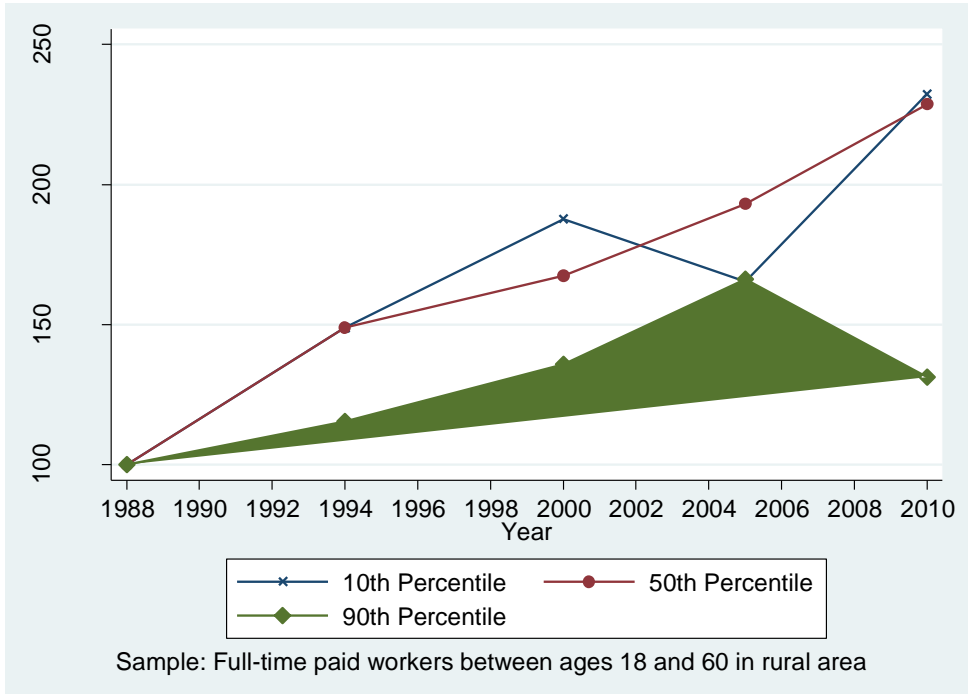

FIGURE A1. INDEXED WAGE INEQUALITY IN RURAL INDIA 


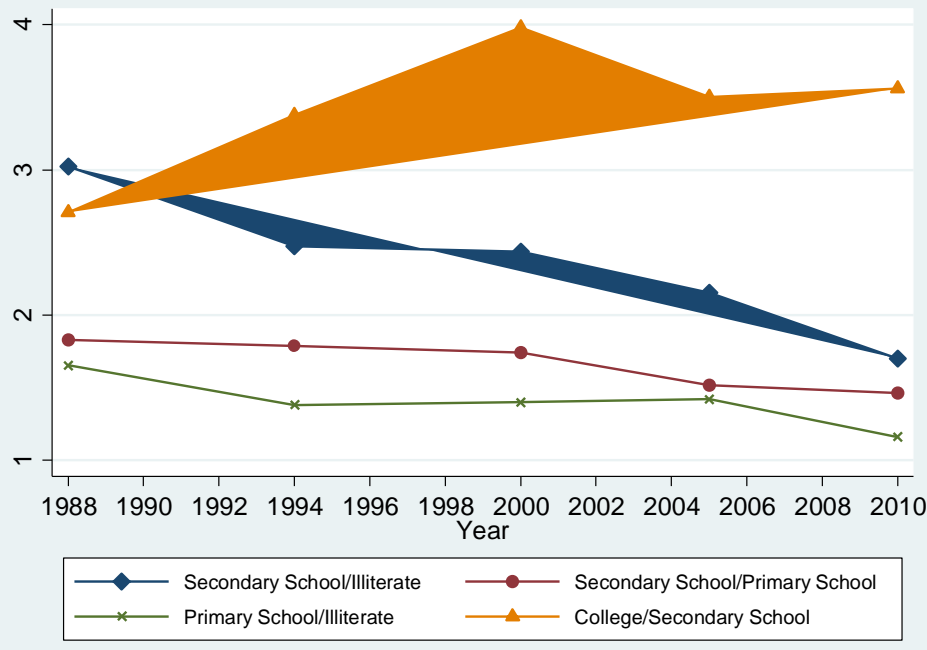

Sample: Full-time paid workers between ages 18 and 60

FIGURE A2. TREND OF SKILL PREMIUM IN RURAL INDIA 


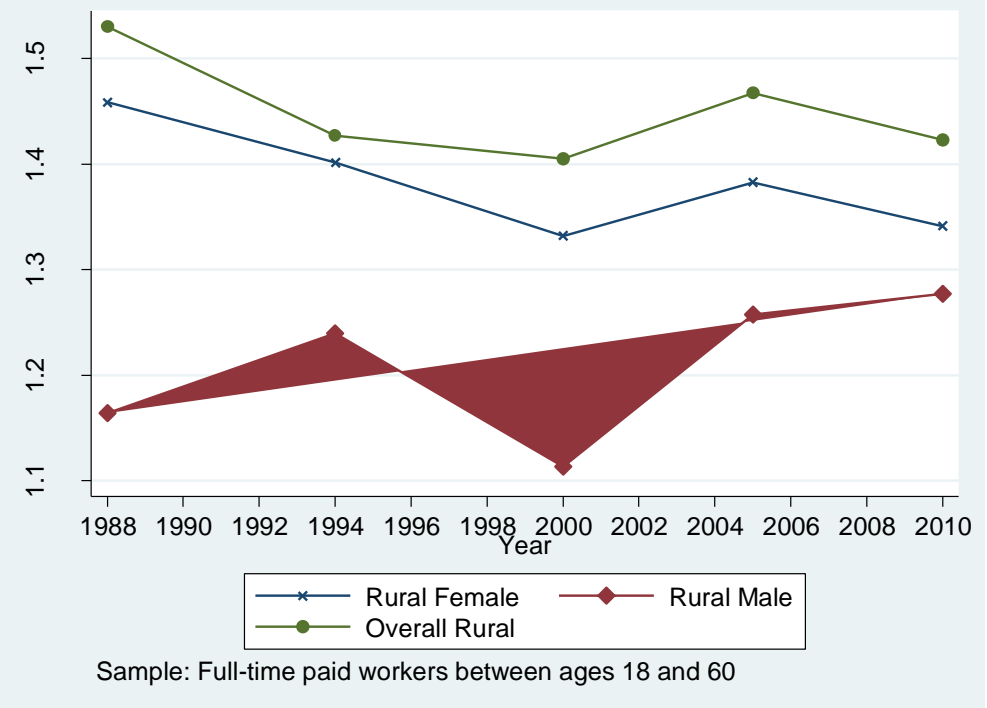

FIGURE A3. RESIDUAL WAGE INEQUALITY IN RURAL INDIA 


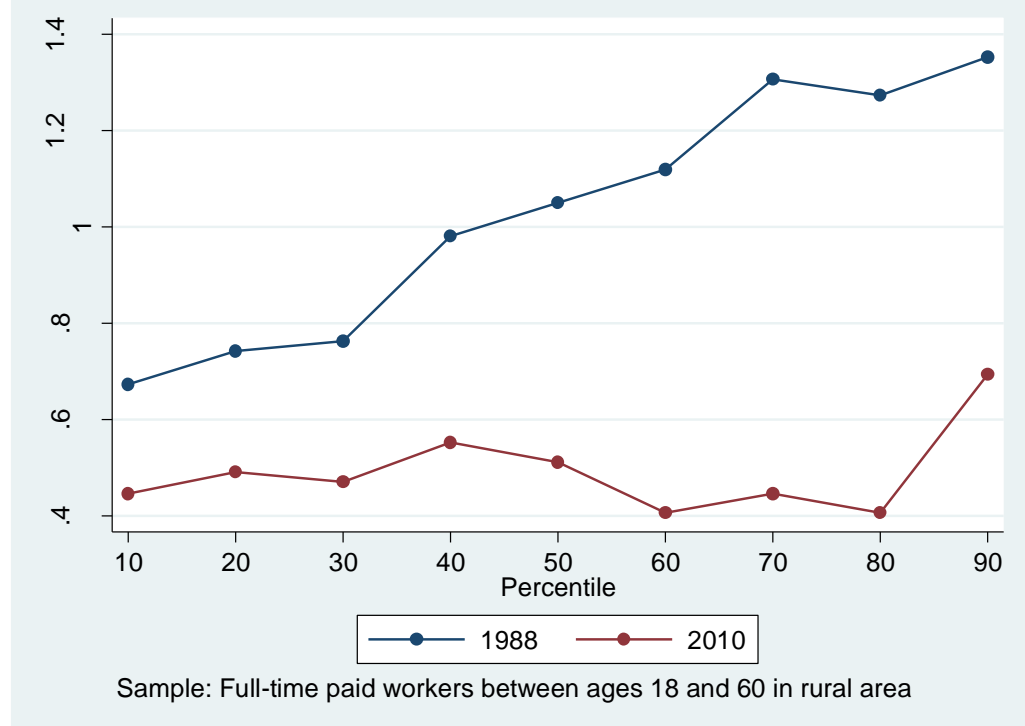

FIGURE A4. GENDER LOG WAGE GAP IN RURAL INDIA 


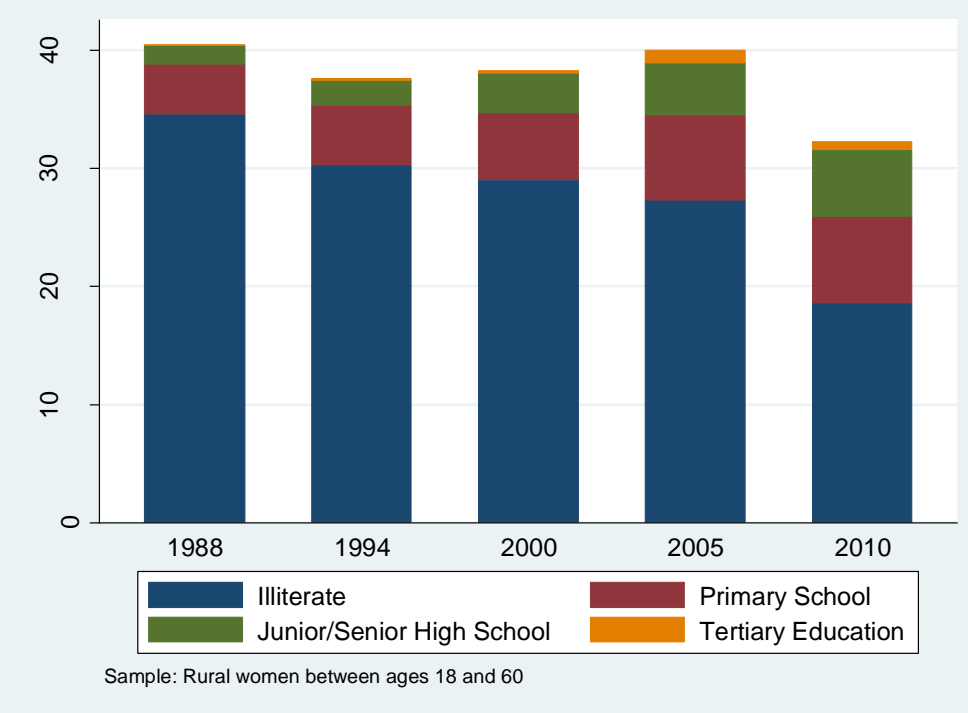

FIGURE A5. FEMALE LABOR FORCE PARTICIPATION RATE IN RURAL INDIA 